\title{
Indeks til Poetik/Kultur \& Klasse 1-52
}

Udarbejdet af Lisbeth Nielsen

\author{
Bemerkninger til indekset
}

I forfatterregisteret er artikleme opstillet alfabetisk efter forfatternes efternavne. Har en forfatter skrevet flere artikler, er de herefter opstillet kronologisk. Ved dobbeltnaune er der henvisninger. Bog- og tidsskriftanmeldere er ikke medtaget $i$ forfatterregisteret, men er medtaget $i$ serskilt gruppe under anmeldelser, jof. nedenfor.

Emneregisteret er inddelt $i$ overordnede emnekategorier, og er opstillet alfabetisk efter emne. Indferslerne er opstillet kronologisk under de enkelte emner og derefter efter sidetal, hvis der er flere artikler fra samme nummer under et emne. En undtagelse for den kronologiske opstilling under emner er grupperne Litlrraturanalyser og skanlitterare forfatterskaber og Videnskabelige forfattere, hvor artiklerne er ordnet alfabetisk efter omhandlede forfattere. Hvis en artikels emne har krevet flere placeringer, vil den stå under flere emner, men det er sagt begrenset. Emneregisteret starter s. 90.

() efter indforslerne er mine tilfajelser.

Anmeldelser er alfabetisk opstillet efter forfatter(e) til de anmeldte boger. Anmelder(e) samt anmeldelsens titel er nevnt i parentes. Anmeldelsesregisteret starter s. 102.

\section{Forfatterregister}

$A$

Agger, Gunhild: Lenin, revolutionen og Tolstoj. Poetik 21; 1974, 6. årg. nr. 1, s. 19-49.

-: Det sovjetiske samfund og oppositionen. Kultur \& Klasse 29; 1977, s. 11-33.

-: Mellem jorden og jernet: en analyse of $L$. $N$. Tolstojs 'Anna Karenina'. Kultur \& Klasse 37 ; 1980 , s. $89-120$.

-: Tradition og forandring: - en analyse af 'Elskere elsk' og 'Stammerne'. Kultur \& Klasse 42; 1982, s. 12-44.

Agger, Gunhild og Peter Madsen: Lukács, romanen, realisme (forord). Kultur \& Klasse 37; 1980, s. 5-6.

Alsvik, Torkild et al.: Proleter kultur i Norge $i$ 1930-åra. Poetik 23; 1975, 6. årg. nr. 3, s. 106-130.

Andersen, Hans Jørgen: Et ideologisk perspektiv $i$ den franske ny-kritik. Poetik; 1968, serie I nr. 3, s. 11-25.

Andersen, John og Claus Jørgensen: Omkring Jordens Salt: - en analyse af en film og dens tilblivelse. Kultur \& Klasse 36; 1979, s. 104135.

Andersen, Lizzie Ørvad se Ørvad Andersen, Lizzie

Andersen, Tine: Omkring 'Else Kant'. Kultur \& Klasse 39; 1980, s. 102-112.

Andkjær Olsen, Ole: Hoorfor skrive, når vi dog skal do?': en analyse af J. P. Jacobsens 'Arabesk til en Haandtegning af Michel Angelo'. Poetik; 1971, 4. årg. nr. 2-3, s. 106-121.

-: Om okonomiens teori og teoriens akonomi: bidrag til konsumtionens semiotik. Poetik; 1971, 4. årg. nr. 4, s. 72-85. 
-: Omkring Lacan/Laplanche-kontroversen: introduktion til Jean Laplanche: 'Sproget og det ubevidste'. Kultur \& Klasse 47; 1983, s. 731.

Ariès, Philippe: Mentalitetshistorie. (Oversat af Peter Larsen.) Kultur \& Klasse 48; 1983, s. 30-57.

Aspelin, Kurt: Om konsten att bortse frän motsättningar: några synspunkter på sempirio-positivistisk " kultur- och litteratursociologi. Poetik 20; 1972-73, 5. årg. nr. 4, s. 3-15.

Avlund Frandsen, Hans Erik: Historieproblemet hos Kierkegaard og den unge Marx. Poetik 26; 1975, 7. årg. nr. 2, s. 7-90.

\section{$B$}

Baggesen, Søren: Litteraturhistorikerens problem som traditionsberer: - et arbejdspapir. Kultur \& Klasse 32; 1978, s. 18-31.

Bang, Jørgen: Litteraturkritikkens perspektiv. Poetik; 1969, serie II nr. 2, s. 39-43.

Barthes, Roland: Fra verk til tekst. (Oversat af Peter Madsen.) Kultur \& Klasse 40; 1981, s. 36-43.

-: Den tredie mening: forskningsnotater om nogle stills fra S. M. Eisensteins film. (Oversat af Peter Larsen.) Kultur \& Klasse 44; 1982 , s. $20-40$.

Beck Nielsen, Steen og Lars Fuglsang: Fredric Jameson og den historiske udvikling af det narrative. Kultur \& Klasse 49; 1984, s. 62-93.

Behrendt, Poul: Tekst, historie og samfund: om forholdet mellem teori og praksis hos Jorgen Bonde Jensen, hos Villy Sorensen - og $i$ den kritiske videnskab. Kultur \& Klasse 35; 1979, s. 92145.

Billing, Greta: Fransk kultur- og regionalpolitikk i 1960 og 70 årene: en impresjonistisk studie. Poetik 23; 1975, 6. årg. nr. 3, s. 67-73.

Blach, Thomas: Dualisme - kunst og politik: en autoriter tendens $i$ den antiautoritere kulturkritik. Kultur \& Klasse 45; 1982, s. 71-98.

Bondebjerg, Ib: Bertolt Brecht. Ideologikritiker og proletarisk praktikant: om litteraturteori og -praksis hos Brecht og ansatserne til en proletarisk kulturteori i Sovjetunionen og Tyskland i mellemkrigstiden. Poetik 25; 1975, 7. årg. nr. 1, s. 38-115.

-:Parti, Klasse og kulturrevolution: en replik. Poetik 25; 1975, 7. årg. nr. 1, s. 126-135.
-: Historien, traditionen og arbejdererindringen: om den borgerlige kultur og arbejderkulturen $i$ (litteratur)historien. Kultur \& Klasse $35 ; 1979$, s. 67-91.

Bondebjerg, Ib \& Anker Gemzøe: Arbejderlitteratur - proletarisk litteratur - socialistisk litteratur: historisk-teoretisk indledning (temaindl.). Kultur \& Klasse 42; I982, s. 5-11.

Boserup, Ivan: Hvem skrev Tibul for? (Debat om Jens Juhl Jensen: Poesi og talforhold. Tibuls elegier, i Poetik I.1.) Poetik; 1968, serie I nr. 4, s. 65-67.

Bostrup, Lars, Peter Brask og Carsten Hansen: Leserens gestaltning af en litterer tekst. Poetik; 1970, 3. årg. nr. 3, s. 237-250.

Brandt, Per Aage: Strukturalisme på empirisk grundlag. Poetik; 1967, serie I nr. 1, s. 1747.

-: Svar til Poul Nielsen (Debat). Poetik; 1967, serie I nr. 2, s. 80-81.

-: Den ny kritik i Frankrig: en introduktion. Poetik; 1968, serie I nr. 3, s. 8-10.

-: En ren kritik? Poetik; 1968, serie I nr. 3, s. 56-71.

-: Debat. (Om Peter Madsen: Strukturel digtbeskrivelse, i Poetik I.1.) Poetik; 1968, serie I nr. 3, s. 105-107.

-: Matematik og metaforik (Debat om P. A. Brandt: Strukturalisme på empirisk grundlag i Poetik I.1). Poetik; 1968, serie I nr. 4, s. 7172.

-: Fiktivitet og semiologi. Poetik; 1969, serie II nr. 2, s. 44-59.

-: Greimas og videnskabelighedens struktur. Poetik; 1969, serie II nr. 3, s. 91-93.

-: Tekstens teori. Poetik; 1970, serie II nr. 4, s. 21-50.

-: Barthes og den semiologiske model. Poetik; 1970, 3. årg. nr. 1, s. 87-95.

-: Seksualitet og tekstualitet/Color love 3. Poetik; 1970, 3. årg. nr. 3, s. 292-296.

-: En sang om mennesket og magten. Poetik; 1970, 3. årg. nr. 4, s. 323-328.

-: Den vilde skrift. Poetik; 1970, 3. årg. nr. 4, s. 383-400.

-: Om dannelsen, uddannelsen og omdannelsen. Poetik; 1970, 3. årg. nr. 4, s. 415-421.

-: Skriftens nulpunkt og den store blafren. Poetik; 1971, 4. årg. nr. 1, s. 45-54.

-: Ødipus i Memphis. Poetik; 1971, 4. årg. nr. 2-3, s. 191-199. 
Brandt, Per Aage, Peter Madsen og Ralf Pittelkow: Kritik af in ukritisk kritik. (Debat.) Poetik; 1971, 4. årg. nr. 1, s. 91-99.

Brandt, Per Aage se også Mønster Pedersen, Jørgen.

Brask, Peter: Om logiske konstruktions-forskelle mellem wtalesprog" og sskriftsprogu. Poetik; 1969, serie II nr. 1, s. 19-31.

-: Den fremmedgjorte eros: en Blicher-studie. Poetik; 1969, serie II nr. 2, s. 13-38.

-: Kánon, doktrin og historieforfalskning: et eksempel fra gymnasiets danske tekst-tradition. Poetik; 1971, 4. årg. nr. 2-3, s. 65-73.

-: Semantiske beskrivelses-principper: eksempler på nytten af algebraiske grupper ved beskrivelse af betydningsfelter. Poetik 17; 1972, 5. årg. nr. 1, s. 78-117.

Brask, Peter se også Bostrup, Lars.

Brückner, Peter og Gabriele Ricke: $O m$ den estetiske opdragelse af menneskene $i$ arbejderbevegelsen. (Oversat af Lisbeth Gundlund Jensen.) Poetik 25; 1975, 7. årg. nr. 1, s. 10-37.

Busk-Jensen, Lise: Bristede illustioner: om klassekampen i Balzacs roman 'Bristede illusioner' (1837-43) og konsekvenserne af dens fraver $i \mathrm{Lu}$ kács'analyse (fra 1935). Kultur \& Klasse 37; 1980 , s. $76-88$.

-: Psykiske strukturer i Amalie Skrams romaner. Kultur \& Klasse 39; s. 15-44.

-: Moderkerlighed: en kilde til kvindelig kreativitet. Kultur \& Klasse 50; 1985, s. 112-126.

Busk-Jensen, Lise og Inger-Lise Hjordt-Vetlesen: Dansk kvindelitteratur 1885-1920 (temaindl.). Kultur \& Klasse 39; 1980, s. 3-14.

Busk-Jensen, Lise og Åse Lading: Amerikanske kvindebilleder (forord). Kultur \& Klasse 4I; 1981, s. 3-8.

Bürger, Peter: Receptionsforskning. (Oversat af Hans Christian Fink.) Kultur \& Klasse 40; 1981, s. 44-72.

Bækholm, Rigmor: Introduktion til en engelsk tradition. Kultur \& Klasse 35; 1979, s. 5466.

\section{C}

Chauvier, Jean-Marie: Solsjenitsyn: en politisk analyse. (Oversat af John Svendsen.) Kultur \& Klasse 29; 1977, s. 71-128.

\section{D}

Dalsgård, Birgitte: Standskonflikten $i$ Blichers fortellinger. Kultur \& Klasse 46; 1982, s. 7 82.

Dines Johansen, Jørgen: Det fortaltes struktur. Poetik; 1967, serie I nr. 2, s. 55-75.

-: Grimmelshausen: Simplicius Simplicissimus. Poetik; 1968, serie I nr. 3, s. 72-103.

-: Karakter og handling: overvejelser over Aristoteles' poetik. Poetik; 1968, serie I nr. 4, s. 1724.

-: Genreteori. Poetik; 1970, 3. årg. nr. 4, s. 401414.

-: Ideologi-myte-écriture. Poetik; 1971, 4. årg. nr. 2-3, s. 230-242.

Dwinger, Ida og Anne Hjort: Krisebilleder: en analyse af Lisa Alther: 'Kinflicks'. Kultur \& Klasse 41; 1981, s. 76-116.

\section{$E$}

Eagleton, Terry: Kapitalisme, modernisme og postmodernisme. (Oversat af Jørgen Holmgaard.) Kultur \& Klasse 52; 1986, s. 8-25.

Egebak, Jørgen: "Historisme" og "Strukturalisme (Debat). Poetik; 1970, serie II nr. 4, s. $55-70$.

Egebak, Jørgen, Peter Madsen og Helle Munk Thygesen: Målsatningsdebat. Poetik; 1968, serie I nr. 4, s. 51-61.

Egebjerg, Edvard: Der er et yndigt land. Kultur \& Klasse 33; 1978, s. 91-101.

Einersen, Svein se Alsvik, Torkild.

Elias, Norbert: Et blik på en ridders liv. (Oversat af Nils Gunder Hansen.) Kultur \& Klasse 38; 1980, s. 79-96.

\section{F}

Fabricius, Susanne: Foreldreopger og kensidentitet: en analyse af Karen Blixens ungdomsfortalling 'Plojeren'. Kultur \& Klasse 39; 1980, s. 66-75.

Fausing, Bent: Estetik, kommunikation, socialisation. Kultur \& Klasse 30; 1977, s. 36-84.

Feher, Ferenc: Lukács i Weimar: Georg Lukács' klassicisme og hans realismeteori. (Oversat af Flemming Møldrup Jensen.) Kultur \& Klasse 37; 1980, s. 43-75.

Fjord Jensen, Johan: Efter Guldalderkonstruktionens sammenbrud. Kultur \& Klasse 35; 1979, s. 11-37. 
Frederiksen, Lise Lotte: Ungdom og barndom: metodiske problemer omkring historisk-tematisk lesning i gymnasiet og på HF. Kultur \& Klasse $35 ; 1979$, s. 161-173.

Fuglsang, Lars se Beck Nielsen, Sten.

Furuland, Lars: Litteraturen $i$ samhällsdebatten: kommentarer till nagra forskningsresultat inom svensk litteratursociologi. Kultur \& Klasse 42; 1982 , s. $45-60$.

\section{G}

Gemzøe, Anker: Dialogen og den tragiske farce Michael Bachtins teoretiske arbejde. Poetik; 1971, 4. årg. nr. 1, s. 3-44.

-: Processen $i$ Kafkas anti-digtning. Poetik 17; 1972, 5. årg. nr. 1, s. 25-57.

-: Faustus og historien: en sammenlignende analyse af 'Historia von D. Johann Fausten' og Marlowe's 'Doctor Faustus'. Poetik 22; 1974, 6. årg. nr. 2, s. 5-44.

-: Arbejderkultur i Danmark i perioden fra $1890 \mathrm{til}$ 1924. Kultur \& Klasse 31; 1977, s. 31-61.

Gemzøe, Anker se også Bondebjerg, Ib.

Giersing, Morten: Lukács som litteraturkritiker. Poetik 28; 1976, 7. årg. nr. 4, s. 6-54.

-: Massekommunikation. (Forord.) Kultur \& Klasse 36; 1979, s. 5-6.

Gotthardsen, Mette Overgaard se Overgaard Gotthardsen, Mette.

Gourevitch: Tiden som kulturhistorisk problem. (Oversat af Martin Zerlang.) Kultur \& Klasse 48; 1983, s. 90-110.

Greimas, Algirdas-Julien: Grundtrek af en narratio grammatik. (Oversat af Per Aage Brandt.) Poetik; 1969, serie II nr. 3, s. 121.

Grodal, Torben Kragh: Koherens, sandsynlighed, vurdering. (Debat.) Poetik; 1969, serie II nr. 2, s. 67-72.

-: Pontoppidans sexualokonomi: karaktereologien $i$ $P$ 's romaner med serligt henblik på Lykke-Per. Poetik; 1970, 3. årg. nr. 4, s. 329-342.

-: Tilpasning eller fremmedgerelse: Erasmus Montanus og Den 11. juni som ideologiske afgrensninger af enevalden i forhold til feudalisme og liberalisme. Poetik; 1971, 4. årg. nr. 2-3, s. 21-34.

-: Den eventyrlige nekrolati: dødstematikken $i$ nogle H. C. Andersen-texter og relationen til de sociale, sexuelle og skripturelle traumer. Poetik; 1971, 4. årg. nr. 2-3, s. 74-94.
-: Alling og om: handlingsopbygning og verdiunivers i Den grimme Alling og Orneflugt. Poetik; 1971, 4. årg. nr. 2-3, s. 95-105.

-: Klassestruktur og historiesyn i nogle Pontoppidantexter. Poetik; 1971, 4. årg. nr. 2-3, s. 182-190.

-: Tematisk tekstanalyse: en skitsering af tekstanalytisk emneområde. Poetik; 1971, 4. årg. nr. 4, s. $40-55$.

-: Selens lyst og sjelens ubodelige ensomhed: en analyse af Martin A. Hansens Logneren. Poetik 17; 1972, 5. årg. nr. 1, s. 1-24.

-: Nattevagt og den socialhistoriske analyse. Poetik 21; 1974, 6. årg. nr. 1, s. 69-88.

-: Hierarki, egteskab og social forandring i Shakespeare's Som man behager, Stormen og Pericles. Poetik 22; 1974, 6. årg. nr. 2, s. 45-74.

-: Efterskrift. Kultur \& Klasse $32 ; 1978$, s. 115-128.

-: Udviklingstendenser og prablemer $i$ fremtidens mediestruktur. Kultur \& Klasse 36; s. 7-18.

-: Frihed og nodvendighed: betragtninger over litteraturens og litteraturundervisningens funktioner. Kultur \& Klasse 38; 1980, s. 97-109.

Grodal, Torben Kragh og Jørgen Holmgaard: Skitse til en litteratur- og bevidsthedshistorisk beskrizelse af perioden 1848-1901 i Danmark. Kultur \& Klasse 32; 1978, s. 60-114.

Grödal, Hanne Tang og Kirsten Busck Mellor: Barmfagre blondiner og hyggelige husmodre: ideologiske kuindebilleder $i$ 40'ernes og 50'ernes USA. Kultur \& Klasse 41; 1981, s. 9-34.

Gudmundsson, Halldor: Ideologikritik og tradition: om Leo Löwenthals litteraturanalyser. Kultur \& Klasse 49; 1984, s. 34-61.

Gunder Hansen, Nils: Subjektets civilisering: en introduktion til Norbert Elias' historiske psykologi. Kultur \& Klasse 38; 1980, s. 50-78.

-: Symbolsk udveksling og historisk antropologi Kultur \& Klasse 48; 1983, s. 111-126.

\section{$H$}

Habermas, Jürgen: Indmarchen $i$ postmoderniteten. (Oversat af Arno Victor Nielsen.) Kultur \& Klasse 51; 1985, s. 105-117.

Hansen, Bent S.: Om Peter Madsen: Strukturel digtbeskrivelse in Poetik 1.1. (Debat.) Poetik; 1968, serie I nr. 3, s. 104-105.

Hansen, Carsten se Bostrup, Lars.

Hansen, Nils Gunder se Gunder Hansen, Nils. 
Harrebye, Leif og Johan Rosdahl: Temalesning og elevsituation. Kultur \& Klasse 35; 1979, s. 189-197.

Harsløf, Olav: Radikalismen. Poetik 23; 1975, 6. årg. nr. 3, s. 95-105.

Hauberg Mortensen, Finn: Sproglige og fortelletekniske iagttagelser $i$ Herman Bang's novelle Irene Holm. Poetik; 1969, serie II nr. 1, s. 54-83.

-: Tre tekster af Tom Kristensen. Poetik; 1970, 3. årg. nr. 3, s. 313-321.

Heller, Agnes: Den eldre Lukács' filosofi. (Oversat af Gert Rosenkvist og Hans Christian Fink.) Kultur \& Klasse 45; 1982, s. 55-70.

Hjordt-Vetlesen, Inger-Lise: Fra familie til individ: om nogle bevegelser $i$ Marie Bregendahls fortelling 'Hanne ved Hejen'. Kultur \& Klasse 39; 1980, s. 76-101.

Hjordt-Vetlesen, Inger-Lise se også BuskJensen, Lise.

Hjort, Anne se Dwinger, Ida.

Holmgren, Ola: Proletärfôffattaran och den litterära institutionen. Kultur \& Klasse 42; 1982 , s. 61-69.

Holmgaard, Jørgen: Gule handsker og rene hender. Poetik; 1970, 3. årg. nr. 3, s. 227-236.

-: Introduktion til numismatikken. Poetik; 1970 , 3. årg. nr. 4, s. 363-381.

-: Lykken er ...: en kortfattet analyse af Henrik Pontoppidans Lykke-Per. Poetik; 1971, 4. årg. nr. 1, s. 55-78.

-: Indledning (til 'Tekstanalyser - ideologikritiske tekster'). Poetik; 1971, 4. årg. nr. 2-3, s. 5-20.

-: Den "forsvundne" produktivitet: en analyse af J. P. Jacobsens 'Niels Lyhne'. Poetik; 1971, 4. årg. nr. 2-3, s. 122-164.

-: Hjertesorg og andre sorger. Poetik 21; 1974, 6. årg. nr. 1, s. 89-101.

-: Kunsten som oplevelse - kunsten som supermarked. Kultur \& Klasse 50; 1985, s. 35-51.

Holmgaard, Jørgen \& Ralf Pittelkow: Samfundskritik eller sjalepleje?: - Aage Henriksen og Fiskerne. Poetik; 1971, 4. årg. nr. 4, s. 1-39.

Holmgaard, Jørgen se også Grodal, Torben Kragh.

Hougaard, Jens: Argumenter for historien. Kultur \& Klasse $32 ; 1978$, s. 5-17.

-: Dansk $i$ historien. Kultur \& Klasse 35; 1979, s. $146-160$.
Hvidt-Nielsen, Grete: Sociale utopier: - Strindbergs ideologiske ud-og afviklinger (1879-1887). Poetik; 1971, 4. årg. nr. 2-3, s. 165-181.

Hørlych Karlsen, Hugo: Realisme og realitet: den nye virkelighed og den nye (ny) realisme. Poetik 23; 1975, 6. årg. nr. 3, s. 74-94.

$I$

Iversen, Irene: Grunnlaget for en litteratursosiologi. Poetik; 1969, serie II nr. 1, s. 5-18.

Iversen, Irene se også Alsvik, Torkild.

$J$

Jakobsen, Karen Sonne se Sonne Jakobsen, Karen.

Jameson, Fredric: Post-modernismen og den sene kapitalismes kulturelle logik. (Oversat af Peter Kirkegaard.) Kultur \& Klasse 51; 1985, s. 82-104.

Jansen, Steen: Malsetningsdebat I. Poetik; 1969, serie II nr. 1, s. 84-90.

Jensen, Flemming Møldrup se Møldrup Jensen, Flemming.

Jensen, Jens Juhl se Juhl Jensen, Jens.

Jensen, Johan Fjord se Fjord Jensen, Johan.

Jerslev, Anne: Cassavetes' kvindefilm. Kultur \& Klasse 41 ; 1981, s. 117-144.

Johansen, Jørgen Dines se Dines Johansen, Jørgen.

Juhl Jensen, Jens: Poesi og talforhold. Tibuls elegier. Poetik; 1967, serie I nr. 1, s. 87-99.

-: Tibuls poetiske teknik - et svar til Karsten Olesen og Ioan Boserup. Poetik; 1968, serie I nr. 4, s. 67-69.

Juncker, Beth: Kvindekamp, klassekamp og puritanisme: en analyse af Karen Sundts kolportage roman, Arbeiderliv, fra 1901. Kultur \& Klasse 42; 1982, s. 70-112.

Jørgensen, Claus se Andersen, John.

$K$

Kappel, Jette, Annette Nielsen og Lise Winther-Jensen: Frygten er levende: - en analyse af Sylvia Plaths Glasklokken. Kultur \& Klasse 41; 1981, s. 35-75.

Karlsen, Hugo Hørlych se Hørlych Karlsen, Hugo.

Karlsten, Torodd se Alsvik, Torkild.

Karol, K. S.: Interview med Michel Foucault. 
(Oversat af Victor Hjort.) Kultur \& Klasse $30 ; 1977$, s. 23-35.

Kirkegaard, Peter: Lille receptionshistorie: indledning til Harald Steinhagen: Om Walter Benjamins allegoribegreb. Kultur \& Klasse 47; 1983, s. 91-94.

Kjørup, Søren: Filmanalysen: tanker om filmvidenskabens fundament. Poetik; 1969, serie II nr. 2, s. 1-12.

-: Om forskellen mellem de konventionelle og de säkaldt naturlige tegn. Poetik; 1970, 3. årg. nr. 1, s. 79-86.

Knudsen, Nils Lykke se Lykke Knudsen, Nils.

Kock, Christian: Literaritet. Poetik; 1969, serie II nr. 1, s. 32-47.

-: Bemerkninger til en textteori: forsag $i$ retning af flere kriterier for textbeskrivelse. Poetik; 1970 , 3. årg. nr. 2, s. 178-204.

Kracauer, Siegfried: Fotografiet. (Oversat af Peter Larsen.) Kultur \& Klasse 44; 1982 , s. 7-19.

Kaarsholm, Preben: Pontoppidans Nattevagt. Poetik 21; 1974, 6. årg. nr. 1, s. 50-68.

-: Defoe's Robinson Crusoe og kapitalismens udvikling $i$ England. Poetik 22; 1974, 6. årg. nr. 2, s. 75-134.

-: George Thomson og antikken: om nogle livtag med den historiske materialisme. Poetik 22, 1974, 6. årg. nr. 2, s. 146-189.

-: Engelske excentrikere: E. P. Thompson, The Poverty of Theory og den engelske althusserianisme. Kultur \& Klasse 43; 1982, s. 5-41.

-: Lukács, kulturen og muligheden af et andet liv: fra Sondagskredsen til de flyvende universiteter. Kultur \& Klasse 45; 1982, s. 7-23.

-: Imperialisme og masochisme $i$ Olive Schreiners romaner. Kultur \& Klasse 50; 1985, s. 67 82.

-: Imperialisme som fin-de-siècle modernisme: engelsk 'new journalism' $i$ 1890'erne. Kultur \& Klasse 51; 1985, s. 46-61.

$L$

Lading, Åse se Busk-Jensen, Lise.

Laplanche, Jean: Sproget og det ubevidste. (Oversat af Ole Andkjær Olsen og Steffen Jørgensen.) Kultur \& Klasse 47; 1983, s. 33-71 (se rettelse Kultur \& Klasse 48; s. 132).
Larsen, Peter: Forord. (Om fotografi.) Kultur \& Klasse 44; 1982, s. 3-6.

-: Den plastiske tanke: Pierre Francastels kunstsociologi og mentalitetshistorien. Kultur \& Klasse $48 ; 1983$, s. $58-89$.

-: Erindringsbilleder: fra det indre filmmuseum. Kultur \& Klasse 50; 1985, s. 8-22.

Lauridsen, Palle Schantz se Schantz Lauridsen, Palle.

(Lenin, V. I.): Lenin om Tolstoj. (Oversat af Gunhild Agger og Jørgen Holmgaard.) Poetik 21; 1974, 6. årg. nr. 1, s. 5-18.

Levy, Jette Lundbo: Mennesket som romanhelt. Poetik; 1971, 4. årg. nr. 2-3, s. 35-47.

-: Kvinden som bevidsthedsproducent. Poetik 20; 1972-73, 5. årg. nr. 4, s. 63-76.

Liebst, Asger: Småborgeren og skandalen: - skandalepressen og smáborgerlig socialkarakter $i$ 1830'emes Kabenhavn. Kultur \& Klasse 46; 1982, s. 83-100.

Lindhardtsen, Jytte: Norm og afuigelse. Kultur \& Klasse 35; 1979, s. 174-188.

Lindner, Rolf: Klassespecifikke aspekter af kritik$k e n$ af vareastetikken. (Oversat af Nina Lykke.) Kultur \& Klasse 36; 1979, s. 19-32.

Lukács, Georg: Romanen. (Oversat af Arno Victor Nielsen.) Kultur \& Klasse 37; 1980, s. 7-42.

-: Bolsjevismen som moralsk problem. (Oversat af Preben Kaarsholm.) Kultur \& Klasse 45; 1982, s. 49-54.

Lund Nielsen, Jens Peter: Klassekampens fysiologi $i$ Les Rougon-Macquart. Poetik; 1970, 3. årg. nr. 2, s. 108-129.

Lykke Knudsen, Nils: Reklame og mening. Poetik; 1971, 4. årg. nr. 4, s. 56-71.

\section{$M$}

Madsen, Peter: Strukturel digtbeskrivelse. Poetik; 1967, serie I nr. 1, s. 59-86.

-: Svar til Bent S. Hansen og Per Aage Brandt. (Debat.) Poetik; 1968, serie I nr. 3, s. 107123.

-: Noter om Aristoteles' poetik. Poetik; 1968, serie I nr. 4, s. 25-35.

-: Debat. (Kommentar til Jørgen. Egebak: "Historisme« og "Strukturalisme«.). Poetik; 1970, serie II nr. 4, s. 74-76.

-: Det integrerede normbrud: narratologisk analyse. Poetik; 1970, 3. årg. nr. 1, s. 1-20. 
-: Kontinuitetens abstrakte overvindelse. Poetik; 1971, 4. årg. nr. 2-3, s. 200-215.

-: Strukturalistisk litteraturvidenskab - kritisk videnskab eller hvad barer teksten? Poetik 17; 1972, 5. årg. nr. 1, s. 58-77.

-: Modsigelsens poetik. Poetik 18, 1972, 5. årg. n. 2, s. 174-208.

-: Begrebsdannelsens uomgangelige odselhed: bemarkninger til Per Aage Brandts efterskrift $i$ Georges Bataille: Den indre erfaring (Rhodos, 1972). Poetik 18; 1972, 5. årg. nr. 2, s. 236248.

-: Litteraturvidenskab og socialvidenskab: til ideologi-analysens socialvidenskabelige begrundelse. Poetik 19; (1973), 5. årg. nr. 3, s. 111-132.

-: Kritikken af den politiske akonomi og "litteratur-sociologir. Poetik 20; 1972-73, 5. årg. nr. 4, s. 16-34.

-: Kulturdebat og kulturpolitik: baggrunden for den aktuelle kulturpolitiske situation $i$ Danmark. Poetik 23; 1975, 6. årg. nr. 3, s. 8-32.

-: Tidens smerte og storbyens atmosfere: joumalisten Herman Bang og hans roman »Stuk«. Poetik 24; 1975, 6. årg. nr. 4, s. 7-31.

-: Socialhistorie, tematik og astetik: bemarkninger til Tidens smerte og storbyens atmosfere. Journalisten Herman Bang og hans roman Stuk. Poetik $24 ; 1975,6$. årg. nr. 4, s. 32-42.

-: Historie og ideologi. Kultur \& Klasse 31; 1977, s. 62-99.

-: De intellektuelles politiske rolle. Kultur \& Klasse 34; 1979, s. 5-8.

-: Radikalisme og humanisme - : to kapitler om dansk ideologi. Kultur \& Klasse 34; 1979, s. 9-43.

-: Historie og bevidsthedshistorie: om uensartethed og ideologisk hegemoni - også et bidrag til kritik af äden fra Frankfurt. Kultur \& Klasse 35; 1979, s. 38-53.

Madsen, Peter se også Agger, Gunhild Brandt, Per Aage - Egebak, Jørgen.

Mai Rasmussen, Viggo: Den sekteriske abstraktion: bemarkninger til en artikel af $\mathrm{Ib}$ Bondebjerg. Poetik 25; 1975, 7. årg. nr. 1, s. 116125.

Mandel, Ernest: Solsjenitsyn, stalinismen og oktoberrevolutionen. (Oversat af John Svendsen.) Kultur \& Klasse 29; 1977, s. 52-64.

Márkus, György: Sjalen og livet: den unge Lukács og "kultur«-problemet. (Oversat af Lisbeth
Hammer og Hans Christian Fink.) Kultur \& Klasse 45; 1982, s. 24-48.

Mattelart, Armand: Kulturimperialisme $i$ de multinationales tidsalder. (Oversat af Jacob Gammelgaard.) Kultur \& Klasse 36; 1979, s. 33-56.

Medvedev, Roj: Hoor blev en million arresterede kommunister af? 'Archipel GULag II'. (Oversat af Nina Lykke.) Kultur \& Klasse 29; 1977, s. 65-70.

Melberg, Arne: Introduktion til århundredeskiftet og tierne. (Oversat af Jørgen Holmgaard.) Poetik 24; 1975, 6. årg. nr. 4, s. 43-55.

Mellor, Kirsten Busck se Grödal, Hanne Tang.

Mjöset, Lars: Forlösningens antinomier: utkast om forholdet mellom Benjamin og Adorno. Poetik 28; 1976, 7. årg. nr. 4, s. 55-103.

Mortensen, Finn Hauberg se Hauberg Mortensen, Finn.

Munk Thygesen, Helle se Egebak, Jørgen.

Møldrup Jensen, Flemming: Modeskribent og modernist: - om camoufleringsbehovet hos Mallarmé. Kultur \& Klasse 51; 1985, s. 34-45.

Møller, Hanne: Kvindesange. Kultur \& Klasse 39; 1980, s. 113-127.

Møller, Lis: Konfrontationer: - en psykoanalytisk inspireret analyse af Klaus Rifbjergs digtsamling - Konfrontation. Kultur \& Klasse 40; 1981, s. 5-35.

-: Der Sandmann og Freuds analyse af fortellingen $i$ Das Unheimliche: - et essay om psykoanalyse og tekstanalyse. Kultur \& Klasse $47 ; 1983$, s. 73-89.

Mønster Pedersen, Jørgen: Skriftens tre-uenighed. Poetik; 1970, serie II nr. 4, s. 51-54.

-: Udviskning af en metafysik: på vej mod en generel Numismatik. Poetik; 1970, 3. årg. nr. 3, s. 277-291.

Mønster Pedersen, Jørgen og Per Aage Brandt: Narratologiske noter. Poetik; 1969, serie II nr. 3, s. 22-37.

-: Flaubert i skriften: en grammatologisk analyse af 'Trois Contes'. Poetik; 1970, 3. årg. nr. 3, s. 251-275.

\section{$N$}

Negt, Oskar: Det borgerlige demokratis misère $i$ Tyskland. (Oversat af Hanne Møller.) Kultur \& Klasse 34; 1979, s. 44-69. 
-: Wallraffs undersøgelsesarbejde $i$ den "tilslorede virkeligheds" regioner. (Oversat af Nina Lykke.) Kultur \& Klasse 36; 1979, s. 78-103.

Nergaard, Trygve se Alsvik, Torkild.

Nielsen, Annette se Kappel, Jette.

Nielsen, Anton: Hyrdedrengen. Kultur \& Klasse $33 ; 1978$, s. $82-90$.

Nielsen, Elo: Narcissisme og beatmusik. Kultur \& Klasse 30; 1977, s. 85-105.

Nielsen, Erik: Jeg-novellen med stadigt hensyn til Peter Seeberg. Poetik; 1969, serie II nr. 3, s. 63-75.

Nielsen, Jens. Peter Lund se Lund Nielsen, Jens Peter.

Nielsen, Poul: Kommentar til Per Aage Brandts Artikel Strukturalisme på empirisk grundlag $i$ poetik I.1. (Debat:) Poetik; 1967, serie I nr. 2, s. 76-80.

-: Svar til Per Aage Brandt. (Debat.) Poetik; 1967, serie I nr. 2, s. 81-82.

Nielsen, Steen Beck se Beck Nielsen, Steen.

Norén, Kjerstin: Konstproduktionens forändrade villkor. Poetik 20; 1972-73, 5. årg. nr. 4, s. 35-44.

-: Kulturpolitik eller kulturkamp? Poetik 23; 1975, 6. årg. nr. 3, s. 44-66.

Norup, Lis: Lon for djevletjeneste. Kultur \& Klasse 51; 1985, s. 62-81.

\section{$O$}

Olesen, Karsten: Juhl Jensen eller Tibul? (Debat om Jens Juhl Jensen: Poesi og talforhold. Tibuls elegier, i poetik I.1). Poetik; 1968, serie I nr. 4, s. 62-65.

-: Semantiske strukturmodeller. Poetik; 1968, serie I nr. 3, s. 26-55.

Olsen, Ole Andkjær se Andkjær Olsen, Ole.

Overgaard Gotthardsen, Mette: Drommebilleder: et forsag til en psyko-social tolkningsmodel for $H$. C. Lumbyes musik $i$ Tivoli omkring midten af 1800-tallet. Kultur \& Klasse 51; 1985 , s. 8-33.

\section{$P$}

Pedersen, Jørgen Mønster se Mønster Pedersen, Jørgen.

Pelikan, Jiri: Debatten $i$ den sovjetiske opposition $i$ dag og det vesteuropaiske venstres ansvar. (Oversat af Nina Lykke.) Kultur \& Klasse 29;
1977, s. 34-51

Pittelkow, Ralf: Skitse til en handlingsmodel. Poetik; 1970, serie II nr. 4, s. 4-20.

-: Den falske historicitet eller Litteraturens maskerade: analyse af historiesynet $i$ Salammbô og L'Éducation sentimentale. Poetik; 1970, 3. årg. nr. 2; s. 130-154.

-: Marxisme og strukturalisme: en introduktion til Lucien Sebag. Poetik; 1970, 3. årg. nr. 3, s. 297-312.

-: Om litteratur som socialt fenomen (semiologiske noter). Poetik; 1970, 3. årg. nr. 4, s. 343-361.

-: Det er (ikke) rart at vere fremmedgjort: analyse af Tenk på et tal og Handeligt uheld. Poetik; 1971, 4. årg. nr. 2-3, s. 243-271.

-: Samfundsteori og tekstteori. Poetik 19; (1973), 5 årg. nr. 3, s. 5-73.

-: Nogle kommentarer til Preben Kaarsholms artikel. (Om Robinson Crusoe.) Poetik 22; 1974, 6. årg. nr. 2, s. 135-145.

Pittelkow, Ralf se også Brandt, Per Aage Holmgaard, Jørgen.

$R$

Rasmussen, Viggo Mai se Mai Rasmussen, Viggo.

Rastier, Francois: Fortellingens flertydighed (I): (forseg pả beskrivelse af Molières 'Dom Juan'). (Oversat af Jørgen Mønster Pedersen.) Poetik; 1970, 3. årg. nr. 1, s. 34-67.

-: Fortellingens flertydighed (II): (forseg på beskrivelse af Molières 'Dom Juan'). (Oversat af Jørgen Mønster Pedersen.) Poetik. 1970, 3. årg. nr. 2, s. 205-226.

Reitan, Rolf: Noter om arbejderlitteraturens politiske historie. Poetik 25; 1975, 7. årg. nr. 1, s. 136-154.

Reitan, Rolf og Carsten Thau: Interview med Peter Brückner. Kultur \& Klasse 30; 1977, s. 7-22.

Ricke, Gabriele se Brückner, Peter.

Rodwell, Hugh: Malsatningsdebat II: the dilemma of Bourgeois Criticism. Poetik; 1969, serie II nr. 1, s. 91-92.

-: Ingen kender natten - H. C. Branner. Poetik; 1969, serie II nr. 3, s. 76-90.

Rosdahl, Johan se Harrebye, Leif.

Rossanda, Rossana: Sartre og den politiske praksis. (Oversat af Lars Pihl Jensen.) Kultur \& Klasse $34 ; 1979$, s. 70-103. 
Røder, Viggo: Om Propp's Morphology of the Folktale. Poetik; 1970, 3. årg. nr. 1, s. 21-33.

-: Textens granser. Poetik 18; 1972, 5. årg. nr. 2, s. 209-222.

Rømhild, Lars Peter: Kommentar til Jargen Egebak: "Historisme» og "Strukturalismer. (Debat.) Poetik; 1970, serie II nr. 4, s. 71-73.

-: N. F. S. Grundtvig: De Levendes Land. Poetik; 1971, 4. årg. nr. 1, s. 79-90.

Rønning, Helge: Det norske arbeiderpartis kulturpolitikk og den statlige kulturplanlegging. Poetik 23; 1975, 6. årg. nr. 3, s. 33-43.

\section{$S$}

Schantz Lauridsen, Palle: Kvermen kan ikke standses: Fantasiens fabel. Kultur \& Klasse 49; 1984, s. 94-115.

Schorske, Carl E.: Politik og fadermord i Freuds 'Drommetydning'. (Oversat af Bodil Folke Frederiksen.) Kultur \& Klasse 49; 1984, s. 8-33.

Schou, Søren: Fortalleren $i$ romanen. Poetik; 1967, serie I nr. 2, s. 5-19.

-: Thomas Manns Doktor Faustus. Poetik; 1967, serie I nr. 2, s. 20-35.

-: Den slette reproduktion og den sentimentale revolte: om poiske-underet $i$ Klaus Rifbjergs Arkivet. Poetik; 1971, 4. årg. nr. 2-3, s. 216-229.

-: Da friheden kom til K. B. Hallen: Don Redmankoncerten 1946. Kultur \& Klasse 50; 1985, s. 83-93.

Secher, Claus: Kunsten og den forvaltede verden: en analyse af Theodor $W$. Adornos astetiske teori og litteraturkritiske praksis. Poetik 18; 1972, 5. årg. nr. 2, s. 133-173.

Siggaard Jensen, Hans: Wittgensteins eastetik. Poetik; 1967, serie I nr. 1, s. 48-58.

-: Om logik, semantik og litteraturvidenskab. Poetik; 1969, serie II nr. 2, s. 60-66.

Skovbjerg, Karen: Frigarelsens grenser: en analyse af Thit Jensens roman Ørkenvandring. Kultur \& Klasse 39; 1980, s. 45-65.

Sonne Jakobsen, Karen: Litteratur som lareproces: - om den unge Brecht. Kultur \& Klasse $31 ; 1977$, s. 100-119.

Steinhagen, Harald: Om Walter Benjamins allegoribegreb. Kultur \& Klasse 47; 1983, s. 95117.

Svane, Marie-Louise: Agnete og havmanden og samfundet: motivet som tradition og metafor.
Poetik; 1971, 4. årg. nr. 2-3, s. 48-64.

-: Social kritik og folkelig tradition $i$ Aakjers roman Vredens Born. Kultur \& Klasse 38; 1980, s. 6-25.

-: Moderkroppen tegner sig: analyse af nogle af Elisabeth Jerichau-Baumanns tegninger. Kultur \& Klasse 50; 1985, s. 52-66.

Svane, Marie-Louise og Marin Zerlang: Indledning. Kultur \& Klasse 43; 1982, s. 3-4.

Syberg, Karen: Virkeligheden der voksede over hovedet: om Christian Kampmanns forfatterskab. Poetik 27; 1976, 7. årg. nr. 3, s. 5-73.

Sørensen, Hans: Begrebet diakroni inden for litteraturforskningen. Poetik; 1970, serie II nr. 4, s. 77-79.

Sørensen, Peer E.: Uddrag af arbejdspapir om litteratursociologi: om kunstverket $i$ cirkulationen. Poetik 20; 1972-73, 5. årg. nr. 4, s. 4562.

Sørensen, Poul Aaby se Aaby Sørensen, Poul.

\section{$T$}

Thau, Carsten: Med-verden eller om-verden: om den samfundsmessige veren og den menneskelige tenkning. Poetik 19; (1973), 5. årg. nr. 3, s. 74-110.

-: Mysterierne i haven til Anstey: - om Peter Greenaways Tegnerens kontrakt. Kultur \& Klasse 50; 1985, s. 94-111.

Thau, Carsten se også Reitan, Rolf.

Thollander, Leif: Kommentarer till den franska folkfronten. Poetik 23; 1975, 6. årg. nr. 3, s. 131-158.

Toft, Jens: Filmsemiologi. Poetik; 1968, serie I nr. 4, s. 5-16.

-: Filmteori og filmanalyse. Poetik; 1969, serie II nr. 3, s. 38-43.

-: Om Samuel Becketts Textes pour rien, IV. Poetik; 1970, 3. ărg. nr. 1, s. 68-72.

-: Analyse af Picasso: Portrat af en ung kvinde. (Sylvette), 1954. Poetik; 1970, 3. årg. nr. 1, s. 73-78.

-: Westerns - Den genskrevne oprindelsesmyte. Kultur \& Klasse 44; 1982, s. 41-79.

$V$

van Dijk, T. A.: Nogle aspekter af en generativtransformationel tekstteori. (Oversat af Annelies van Dijk og Helle Degnbol.) Poetik; 1970, 3. årg. nr. 2, s. 155-177. 
Vester, Michael: Hvad Goethe er for borgeren, er solidariteten for arbejderen. (Oversat af Nina Lykke.) Kultur \& Klasse 31; 1977, s. 9-30.

\section{W}

Walther, Jens: Handlingsbeskrivelse på grundlag af den dynamiske psykologi. Poetik; 1969, serie II nr. 3, s. 44-55.

-: Handlingsbeskrivelse af Breen. Poetik; 1969, serie II nr. 3, s. 56-62.

Wentzel, Knud: Da subjektivt og objektivt blev adskilt: om naturalismen og fortolkningen af $J$. P. Jacobsens Mogens. Poetik; 1969, serie II nr. 1 s. $48-53$.

Wille, Niels Erik: Kritik, padagogik og videnskab. Poetik; 1967, serie I nr. 1, s. 6-16.

-: Formalisering af romanteori. Poetik; 1967, serie I nr. 2, s. 36-54.

Winther-Jensen, Lise se Kappel, Jette.

\section{$Z$}

Zerlang, Martin: Studiet af forkapitalistiske bevidsthedsformer: - principielt belyst og konkret eksemplificeret. Kultur \& Klasse 32; 1978, s. 32-59.

-: Skolelererlitteraturen 1860-1900. Kultur \& Klasse 33; 1978, s. 8-81.

-: Fra land til by med Jeppe Aakjor og Nick Carter: signalement af arbejderlitteraturen omkring
1900. Kultur \& Klasse 38; 1980, s. 26-49.

-: Karneval og katterbål: introduktion til Carlo Ginzburgs forfatterskab. Kultur \& Klasse 40; 1981, s. 73-94.

-: Problemer og perspektiver $i$ fransk mentalitetshistorie. Kultur \& Klasse 48; 1983, s. 8-29.

-: Historien og de gode historier. Kultur \& Klasse 50; 1985, s. 23-34.

Zerlang, Martin se også Svane, MarieLouise.

\section{$\varnothing$}

Ørvad Andersen, Lizzie: En autoriter pedagogik: analyse af serieheftet Den store Kanon. Kultur \& Klasse 36; 1979, s. 57-77.

Østerud, Erik: "Krig med trolde": skisse til et Ibsen-portrett. Kultur \& Klasse 43; 1982, s. 42-80.

A

Aaby Sørensen, Poul: Om konstitueringen af den borgerlige psyke: et bevidsthedshistorisk nybrud, belyst gennem opdragelseslitteratur og romantisk digtning. Kultur \& Klasse 52; 1986, s. 2653.

Aagaard-Mogensen, L.: Semi-matematiske spil med tal. (Debat om Jens Juhl Jensen: Poesi og talforhold. Tibuls elegier, i Poetik I.1.) Poetik; 1968, serie I nr. 4, s. 69-70.

\section{Emneregister}

\section{Arbejderkultur/-litteratur}

Ronning, Helge: Det norske arbeiderpartis kulturpolitikk og den statlige kulturplanlegging. Poetik 23; 1975, 6. årg. nr. 3, s. 33-43.

Alsvik, Torkild et al.: Proleter kultur $i$ Norge $i$ 1930-åra. Poetik 23; 1975, 6. årg. nr. 3, s. 106-130.

Thollander, Leif: Kommentarer till den franska folkfronten. Poetik 23; 1975, 6. ărg. nr. 3, s. 131-158.

Melberg, Arne: Introduktion til århundredeskiftet og tierne. Poetik 24; 1975, 6. årg. nr. 4, s. 4355.

Brückner, Peter og Gabriele Ricke: $O m$ den estetiske opdragelse af menneskene $i$ arbejderbevegelsen. Poetik 25; 1975, 7. årg. nr. 1, s. 1037.

Bondebjerg, Ib: Bertolt Brecht. Ideologikritiker og proletarisk praktikant: om litteraturteori og -praksis hos Brecht og ansatserne til en proletarisk kulturteori i Sovjetunionen og Tyskland i mellemkrigstiden. Poetik 25; 1975, 7. årg. nr. 1, s. $38-115$.

Mai Rasmussen, Viggo: Den sekteriske abstraktion: bemerkninger til en artikel af Ib Bondebjerg. Poetik 25; 1975, 7. årg. nr. 1, s. 116 125.

Bondebjerg, Ib: Parti, klasse og kulturrevolution: en replik. Poetik 25; 1975, 7. årg. nr. 1, s. 126-135. 
Reitan, Rolf: Noter om arbejderlitteraturens politiske historie. Poetik 25; 1975, 7. årg. nr. 1, s. 136-154.

Vester, Michael: Huad Goethe er for borgeren, er solidariteten for arbejderen. Kultur \& Klasse $31 ; 1977$, s. 9-30.

Gemzøe, Anker: Arbejderkultur $i$ Danmark i perioden fra 1890 til 1924. Kultur \& Klasse 31; 1977 , s. $31-61$.

Sonne Jakobsen, Karen: Litteratur som lareproces: - om den unge Brecht. Kultur \& Klasse 31; 1977, s. 100-119.

Bondebjerg, Ib: Historien, traditionen og arbejdererindringen: om den borgerlige kultur og arbejderkulturen $i$ (litteratur)historien. Kultur \& Klasse 35; 1979, s. 67-91.

Zerlang, Martin: Fra land til by med Jeppe Aakjer og Nick Carter: signalement af arbejderlitteraturen omkring 1900. Kultur \& Klasse $38 ; 1980$, s. 26-49.

Bondebjerg, Ib og Anker Gemzøe: Arbejderlitteratur - proletarisk litteratur - socialistisk litteratur: historisk-teoretisk indledning. Kultur \& Klasse 42; 1982, s. 5-11.

Agger, Gunhild: Tradition og forandring: - en analyse af Elskere elsk og Stammerne. Kultur \& Klasse 42 ; , s. 12-44.

Furuland, Lars: Litteraturen i samhällsdebatten: kommentarer till några forskningsresultat inom svensk litteratursociologi. Kultur \& Klasse 42; 1982, s. 45-60.

Holmgren, Ola: Proletärfôrfattaran och den litterära institutionen. Kultur \& Klasse 42; 1982 , s. 61-69.

Juncker, Beth: Kvindekamp, klassekamp og puritanisme: en analyse af Karen Sundts kolportageroman, Arbeiderliv, fra 1901. Kultur \& Klasse 42; 1982, s. 70-112.

Lukács, Georg: Bolsjevismen som moralsk problem. Kultur \& Klasse 45; 1982, s. 49-54.

\section{Bevidsthedshistorie/mentalitetshi-}

\section{storie}

Madsen, Peter: Begrebsdannelsens uomgengelige odselhed: bemarkninger til Per Aage Brandts efterskrift $i$ Georges Bataille: Den indre erfaring (Rhodos 1972). Poetik 18; 1972, 5. årg. nr. 2, s. 236-248.

Thau, Carsten: Med-verden eller om-verden: om den samfundsmassige varen og den menneskelige tenkning. Poetik 19; (1973), 5. årg. nr. 3, s. 74-110.

Hougaard, Jens: Argumenter for historien. Kultur \& Klasse 32; 1978, s. 5-17.

Zerlang, Martin: Studiet af forkapitalistiske bevidsthedsformer: - principielt belyst og konkret eksemplificeret. Kultur \& Klasse 32; 1978, s. 32-59.

Grodal, Torben Kragh og Jørgen Holmgaard: Skitse til en litteratur-og bevidsthedshistorisk beskrivelse af perioden 1848-1901 i Danmark. Kultur \& Klasse $32 ; 1978$, s. 60-114.

Grodal, Torben Kragh: Efterskrift. Kultur \& Klasse 32; 1978, s. 115-128.

Madsen, Peter: Historie og bevidsthedshistorie: om uensartethed og ideologisk hegemoni-også et bidrag til kritik af änden fra Frankfurt. Kultur \& Klasse 35; 1979, s. 38-53.

Gunder Hansen, Nils: Subjektets civilisering: en introduktion til Norbert Elias' historiske psykologi. Kultur \& Klasse 38; 1980, s. 50-78.

Elias, Norberg: Et blik pa en ridders liv. Kultur \& Klasse 38; 1980, s. 79-96.

Zerlang, Martin: Problemer og perspektiver $i$ fransk mentalitetshistorie. Kultur \& Klasse 48; 1983, s. 8-29.

Ariès, Philippe: Mentalitetshistorie. Kultur \& Klasse 48; 1983, s. 30-57.

Larsen, Peter: Den plastiske tanke: Pierre Francastels kunstsociologi og mentalitetshistorien. Kultur \& Klasse 48; 1983, s. 58-89.

Gourevitch, A. Y.: Tiden som kulturhistorisk problem. Kultur \& Klasse 48; 1983, s. 90-110.

Gunder Hansen, Nils: Symbolsk udveksling og historisk antropologi. Kultur \& Klasse 48; 1983, s. 111-126.

Aaby Sørensen, Poul: Om konstitueringen af den borgerlige psyke: et bevidsthedshistorisk nybrud, belyst gennem opdragelse. litteratur og romantisk digtning. Kultur \& Klasse 52; 1986, s. 2653.

\section{Film}

Toft, Jens: Filmsemiologi. Poetik; 1968, serie I nr. 4, s. 5-16.

Kjørup, Søren: Filmanalysen: tanker om filmvidenskabens fundament. Poetik; 1969, serie II nr. 2, s. 1-12.

Toft, Jens: Filmteori og filmanalyse. Poetik; 1969, serie II nr. 3, s. 38-43. 
Andersen, John og Claus Jørgensen: Omkring Jordens Salt: - en analyse af en film og dens tilblivelse. Kultur \& Klasse 36; 1979, s. 104135.

Jerslev, Anne: Cassavetes' kvindefilm. Kultur \& Klasse 41; 1981, s. 117-144.

Barthes, Roland: Den tredie mening: forskningsnotater om nogle stills fra $S$. M. Eisensteins film. Kultur \& Klasse 44; 1982, s. 20-40.

Toft, Jens: Westerns - Den genskrevne oprindelsesmyte. Kultur \& Klasse 44; 1982, s. 41-79.

Larsen, Peter: Erindringsbilleder: fra det indre filmmuseum. Kultur \& Klasse 50; 1985, s. 822.

Thau, Carsten: Mysterierne $i$ haven til Anstey: om Peter Greenaways Tegnerens kontrakt. Kultur \& Klasse 50; 1985, s. 94-111.

\section{Fotografi}

Larsen, Peter: Forord. Kultur \& Klasse 44; 1982, s. 3-6.

Kracauer, Siegfried: Fotografiet. Kultur \& Klasse 44; 1982, s. 7-19.

\section{Genreteori}

Madsen, Peter: Strukturel digtbeskrivelse. Poetik; 1967, serie I nr. 1, s. 59-86.

Schou, Søren: Fortelleren $i$ romanen. Poetik; 1967, serie I nr. 2, s. 5-19.

Wille, Niels Erik: Formalisering af romanteori. Poetik; 1967, serie I nr. 2, s. 36-54.

Dines Johansen, Jørgen: Det fortaltes struktur. Poetik; 1967, serie I nr. 2, s. 55-75.

Hansen, Bent S.: Om Peter Madsen: Strukturel digtbeskrivelse, in Poetik 1.1. Poetik; 1968, serie I nr. 3, s. 104-105.

Brandt, Per Aage: Debat. (Om Peter Madsen: Strukturel digtbeskrivelse, in Poetik I.1.) Poetik; 1968, serie I nr. 3, s. 105-107.

Madsen, Peter: Debat. Svar til Bent S. Hansen og Per Aage Brandt. Poetik; 1968, serie I nr. 3, s. 107-123.

Nielsen, Erik: Jeg»novellen med stadigt hensyn til Peter Seeberg. Poetik; 1969, serie II nr. 3, s. 63-75.

Dines Johansen, Jørgen: Genreteori. Poetik; 1970, 3. årg. nr. 4, s. 401-414.

Lukács, Georg: Romanen. Kultur \& Klasse 37; 1980, s. 7-42.

\section{Historieteori}

Thau, Carsten: Med-verden eller om-verden: om den samfundsmessige varen og den menneskelige tenkning. Poetik 19; 1973, 5. årg. nr. 3, s. 74-110.

Avlund Frandsen, Hans Erik: Historieproblemet hos Kierkegaard og den unge Marx. Poetik 26; 1975, 7. årg. nr. 2, s. 7-90.

Madsen, Peter: Historie og ideologi. Kultur \& Klasse 31; 1977, s. 62-99.

Hougaard, Jens: Argumenter for historien. Kultur \& Klasse $32 ; 1978$, s. 5-17.

\section{Kulturdebat/-politik}

Norén, Kjerstin: Konstproduktionens forändrade villkor. Poetik 20; 1972-73, 5. årg. nr. 4, s. 35-44.

Madsen, Peter: Kulturdebat og kulturpolitik: baggrunden for den aktuelle kulturpolitiske situation i Danmark. Poetik 23; 1975, 6. årg. nr. 3, s. 8-32.

Norén, Kjerstin: Kulturpolitik eller Kulturkamp? Poetik 23; 1975, 6. årg. nr. 3, s. 44-66.

Billing, Greta: Fransk kultur- og regionalpolitikk i 1960 og 70 årene: en impresjonistisk studie. Poetik 23; 1975, 6. årg. nr. 3, s. 67-73.

Harsløf, Olav: Radikalismen. Poetik 23; 1975, 6. årg. nr. 3, s. 95-105.

Agger, Gunhild: Det sovjetiske samfund og oppositionen. Kultur \& Klasse 29; 1977, s. 11-33.

Pelikan, Jiri: Debatten i den sovjetiske opposition $i$ dag og det vesteuropaiske venstres ansvar. Kultur \& Klasse 29; 1977, s. 34-51.

Reitan, Rolf og Carsten Thau: Interview med Peter Brückner. Kultur \& Klasse 30; 1977, s. 7-22.

Madsen, Peter: De intellektuelles politiske rolle. Kultur \& Klasse 34; 1979, s. 5-8.

Madsen, Peter: Radikalisme og humanisme: to kapitler om dansk ideologi. Kultur \& Klasse $34 ; 1979$, s. 9-43.

Negt, Oskar: Det borgerlige demokratis misère $i$ Tyskland. Kultur \& Klasse 34; 1979, s. 4469.

Rossanda, Rossana: Sartre og den politiske praksis. Kultur \& Klasse 34; 1979, s. 70-103.

Blach, Thomas: Dualisme - kunst og politik: en autoriter tendens $i$ den antiautoritare kulturkritik. Kultur \& Klasse 45; 1982, s. 71-98. 


\section{Kunstteori og astetik}

Siggaard Jensen, Hans: Wittgensteins astetik. Poetik; 1967, serie I nr. 1, s. 48-58.

Toft, Jens: Analyse af Picasso: Portret af en ung kvinde (Sylvette), 1954. Poetik; 1970, 3. årg. nr. 1, s. 73-78.

Lykke Knudsen, Nils: Reklame og mening. Poetik; 1971, 4. årg. nr. 4, s. 56-71.

Secher, Claus: Kunsten og den forvaltede verden: en analyse af Theodor $W$. Adomos astetiske teori og litteraturkritiske praksis. Poetik 18; 1972, 5. årg. nr. 2, s. 133-173.

Brückner, Peter og Gabriele Ricke: Om den astetiske opdragelse af menneskene i arbejderbevagelsen. Poetik 25; 1975, 7. årg. nr. I, s. 1037.

Mjöset, Lars: Forlösningens antinomier: utkast om forholdet mellom Benjamin og Adorno. Poetik 28; 1976, 7. årg. nr. 4, s. 55-103.

Fausing, Bent: Estetik, kommunikation, socialisation. Kultur \& Klasse 30; 1977, s. 36-84.

Lindner, Rolf: Klassespecifikke aspekter af kritik$k e n$ af vareastetikken. Kultur \& Klasse 36; 1979, s. 19-32.

Feher, Ferenc: Lukács i Weimar: Georg Lukács' klassicisme og hans realismeteori. Kultur \& Klasse 37; 1980, s. 43-75.

Bürger, Peter: Receptionsforskning. Kultur \& Klasse 40; 1981, s. 44-72.

Márkus, György: Sjalen og livet: den unge Lukács og "kulturw-problemet. Kultur \& Klasse 45; 1982, s. 24-48.

Heller, Agnes: Den aldre Lukács' filosofi. Kultur \& Klasse 45; 1982, s. 55-70.

Blach, Thomas: Dualisme - kunst og politik: en autoriter tendens $i$ den antiautoritere kulturkritik. Kultur \& Klasse 45; 1982, s. 71-98.

Larsen, Peter: Den plastiske tanke: Pierre Francastels kunstsociologi og mentalitetshistorien. Kultur \& Klasse 48; 1983, s. 58-89.

Holmgaard, Jørgen: Kunsten som oplevelse kunsten som supermarked. Kultur \& Klasse 50; 1985, s. 35-51.

Jameson, Fredric: Post-modemismen og den sene kapitalismes kulturelle logik. Kultur \& Klasse 51; 1985, s. 82-104.

Habermas, Jürgen: Indmarchen i postmoderniteten. Kultur \& Klasse 51; 1985, s. 105-117.

Eagleton, Terry: Kapitalisme, modermisme og postmodernisme. Kultur \& Klasse 52; 1986, s. 8-25.

\section{Kvindebilleder/-film og -litteratur}

Levy, Jette Lundbo: Kvinden som bevidsthedsproducent. Poetik 20; 1972-73, 5. årg. nr. 4, s. 63-76.

Busk-Jensen, Lise og Inger-Lise Hjordt-Vetlesen: Dansk kvindelitteratur 1885-1920. Kultur \& Klasse 39; 1980, s. 3-4.

Busk-Jensen, Lise: Psykiske strukturer $i$ Amalie Skrams romaner. Kultur \& Klasse 39; 1980, 's. 15-44.

Skovbjerg, Karen: Frigerelsens grenser: en analyse af Thit Jensens roman Ørkenvandring. Kultur \& Klasse 39; 1980, s. 45-65.

Fabricius, Susanne: Foreldreopgar og kansidentitet: en analyse af Karen Blixens ungdomsfortalling Plejeren. Kultur \& Klasse 39; 1980, s. 66-75.

Hjordt-Vetlesen, Inger-Lise: Fra familie til individ: om nogle bevagelser $i$ Marie Bregendahls fortalling Hanne ved Hajen. Kultur \& Klasse 39; 1980, s. 76-101.

Andersen, Tine: Omkring Else Kant. Kultur \& Klasse 39; 1980, s. 102-112.

Møller, Hanne: Kvindesange. Kultur \& Klasse 39 ; 1980, s. 113-127.

Busk-Jensen, Lise og Åse Lading: Amerikanske kvindebilleder. Kultur \& Klasse 41; 1981, s. 3-8.

Grödal, Hanne Tang og Kirsten Busck Mellor: Barmfagre blondiner og hyggelige husmedre: ideologiske kvindebilleder $i$ 40'ernes og 50'ernes USA. Kultur \& Klasse 41; 1981, s. 9-34.

Kappel, Jette, Annette Nielsen og Lise Winther-Jensen: Frygten er levende: - en analyse af Sylvia Plaths Glasklokken. Kultur \& Klasse 41; 1981, s. 35-75.

Dwinger, Ida og Anne Hjort: Krisebilleder: en analyse af Lisa Alther: Kinflicks. Kultur \& Klasse 41; 1981, s. 76-116.

Jerslev, Anne: Cassavetes' kvindefilm. Kultur \& Klasse 41; 1981, s. 117-144.

Juncker, Beth: Kvindekamp, klassekamp og puritanisme: en analyse af Karen Sundts kolportageroman, Arbeiderliv, fra 1901. Kultur \& Klasse 42; 1982, s. 70-112.

Svane, Marie-Louise: Moderkroppen tegner sig: analyse af nogle af Elisabeth Jerichau-Baumanns tegninger. Kultur \& Klasse 50; 1985, s. 52 66.

Busk-Jensen, Lise: Moderkerlighed: en kilde til kvindelig kreativitet. Kultur \& Klasse 50; 1985, s. 112-126. 


\section{Litteraturanalyser og skonlitterere forfatterskaber}

Agnete og havmanden. Svane, Marie-Louise: $A g$ nete og havmanden og samfundet: motivet som tradition og metafor. Poetik; 1971, 4. årg. nr. 2-3, s. 48-64.

Alther, Lisa: Kinflicks. (Dausk: Levende billeder.) Dwinger, Ida og Anne Hjort: Krisebilleder: en analyse af Lisa Alther: Kinflicks. Kultur \& Klasse 41; 1981, s. 76-116.

Andersen, H. C. Grodal, Torben Kragh: Den eventyrlige nekrolati: dodstematikken $i$ nogle $H$. C. Andersen-texter og relationen til de sociale, sexuelle og skripturelle traumer. Poetik; 1971, 4. årg. nr. 2-3, s. 74-94.

Andersen, H. C.: Den grimme Elling. Grodal, Torben Kragh: AElling og gm: handlingsopbygning og verdiunivers $i$ Den grimme Elling, og $\emptyset r$ neflugt. Poetik; 1971, 4. årg. nr. 2-3, s. 95105.

Andersen, H. C.: Hjertesorg. Holmgaard, Jorgen: Hjertesorg og andre sorger. Poetik 21; 1974, 6. årg. nr. 1, s. 89-101.

Balzac, Honoré de: Bristede illusioner. Busk-Jensen, Lise: Bristede illusioner: om klassekampen $i$ Balzacs roman Bristede illusioner (1837-1843) og konsekvenseme af dens fravar i Lukács' analyse (fra 1935). Kultur \& Klasse 37; 1980, s. 76-88.

Bang, Herman: Irene Holm. Hauberg Mortensen, Finn: Sproglige og fortalletekniske iagttagelser $i$ Herman Bang's novelle Irene Holm. Poetik; 1969, serie II nr. 1, s. 54-83.

Bang, Herman: Stuk. Madsen, Peter: Tidens smerte og storbyens atmosfere: journalisten Herman Bang og hans roman Stuk. Poetik 24; 1975, 6. årg. nr. 4, s. 7-31.

Madsen, Peter: Socialhistorie, tematik og astetik: bemerkninger til Tidens smerte og storbyens atmosfere. Joumalisten Herman Bang og hans roman Stuk. Poetik 24; 1975, 6. årg. nr. 4, s. $32-42$.

Beckett, Samuel: Textes pour rien, IV. Toft, Jens; Om Samuel Becketts Textes pour rien, IV. Poetik; 1970, 3. årg. nr. 1, s. 68-72.

Blicher, St. St. Dalsgård, Birgitte: Standskonfikten $i$ Blichers fortellinger. Kultur \& Klasse 46; 1982, s. 7-82.

Blicher, St. St.: Hosekremmeren, - Marie. Brask, Peter: Den fremmedgjorte eros: en Blicher-stu- die. Poetik; 1969, serie II nr. 2, s. 13-38.

Blixen, Karen: Plojeren. Fabricius, Susanne: Foreldreopgor og kensidentitet: en analyse af $\mathrm{Ka}$ ren Blixens ungdomsforlalling Plojeren. Kultur \& Klasse 39 ; 1980, s. 66-75.

Bodelsen, Anders: Hendeligt uheld, - Tenk på et tal. Pittelkow, Ralf: Det er (ikke) rart at vere fremmedgjort: analyse af Tenk på et tal og Hendeligt uheld. Poetik; 1971, 4. årg. nr. 2-3, s. 243-271.

Bodelsen, Anders se også Kampmann, Christian.

Branner, H. C.: Ingen kender natten. Rodwell, Hugh: Ingen kender natten - H. C. Branner. Poetik; 1969, serie II nr. 3, s. 76-90.

Brecht, Bertolt. Sonne Jakobsen, Karen: Litte ratur som lareproces: - om den unge Brecht. Kultur \& Klasse 31; 1977, s. 100-119.

Bregendahl, Marie: Hanne ved Hejen. HjordtVetlesen, Inger-Lise: Fra Familie it individ: om nogle bevegelser $i$ Marie Bregendahls fortelling Hanne ved Hojen. Kultur \& Klasse 39; 1980, s. 76-101.

Defoe, Daniel: Robinson Crusoe. Kaarsholm, Preben: Defoe's Robinson Crusoe og kapitalismens udvikling $i$ England. Poetik 22; 1974, 6. årg. nr. 2, s. 75-134.

Pittelkow, Ralf: Nogle kommentarer til Preben. Kaarsholms artikel. Poetik 22; 1974, 6. årg. nr. 2, s. 135-145.

Ditleusen, Tove. Busk-Jensen, Lise: Moderkerlighed: en kilde til kvindelig kreativitet. Kultur \& Klasse 50; 1985, s. 112-126.

Dostojevski, Fjodor. Gemzøe, Anker: Dialogen og den tragiske farce - Michael Bachtins teoretiske arbejde. Poetik; 1971, 4. årg. nr. 1, s. 3-44.

Eluard, Paul: Notre année. Brandt, Per Aage: Den vilde skrift. Poetik; 1970, 3. årg. nr. 4 s. 383-400.

Ewald; Johannes: Levnet og Meeninger. Levy, Jette Lundbo: Mennesket som romanhelt Poetik; 1971, 4. årg. nr. 2-3, s. 35-47.

Flaubert, Gustave: L'Éducation sentimentale, - Salammbô. Pittelkow, Ralf: Den falske historicitet eller Litteraturens maskerade: analyse af historiesynet i Salammbô og L'Éducation sentimentale. Poetik; 1970, 3. årg. nr. 2, s. 130-154.

Flaubert, Gustave: Trois Contes. Mønster Pedersen, Jargen og Per Aage Brandt: Flaubert $i$ skriften: en grammatologisk analyse af Trois 
Contes. Poetik; 1970, 3. årg. nr. 3, s. 251275.

Grimmelshausen, H.J. C. von: Simplicius Simplicissimus. Dines Johansen, Jørgen: Grimmelshausen: Simplicius Simplicissimus. Poetik; 1968, serie I nr. 3, s. 72-103.

Grundtvig, N. F. S.: De Levendes Land. Romhild, Lars Peter: N.F. S. Grundtvig: De Levendes Land. Poetik; 1971, 4. ărg. nr. 1, s. 7990.

Gräs, Ulrik: Elskere elsk, - Stammeme. Agger, Gunhild: Tradition og forandring: - en analyse af Elskere elsk og Stammerne. Kultur \& Klasse 42; 1982, s. 12-44.

Hansen, Martin A.: Logneren. Grodal, Torben Kragh: Salens lyst og sjelens ubodelige ensomhed: en analyse af Martin A. Hansens Logneren. Poetik 17; 1972, 5. årg. nr. 1, s. 1-24.

Hoffmann, E. T. A.: Der Sandmann. Møller, Lis: Der Sandmann og Freuds analyse af fortellingen i Das Unheimliche: et essay om psykoanalyse og tekstanalyse. Kultur \& Klasse 47; 1983, s. 73-89.

Holberg, Ludvig: Den 11. juni, - Erasmus Montanus. Grodal, Torben Kragh: Tilpasning eller fremmedgarelse: Erasmus Montanus og Den 11 . juni som ideologiske afgrensninger af enevelden $i$ forhold til feudalisme og liberalisme. Poetik; 1971, 4. årg. nr. 2-3, s. 21-34.

Ibsen, Henrik. Østerud, Erik: Krig med trolde: skisse til et Ibsen-portrett. Kultur \& Klasse 43; 1982, s. 42-80.

Jacobsen, J. P.: Arabesk til en Haandtegning af Michel Angelo. Andkjar Olsen, Ole: Horfor skrive, nair vi dog skal do?: en analyse af J. $P$. Jacobsens Arabesk til en Haandtegning af Michel Angelo. Poetik; 1971, 4. årg. nr. 2-3, s. 106121.

Jacobsen, J. P.: Mogens. Wentzel, Knud: Da subjektivt og objektivt blev adskilt: om naturalismen og fortolkningen af J. P. Jacobsens Mogens. Poetik; 1969, serie II nr. 1, s. 48-53.

Jacobsen, J. P.: Niels Lyhne. Holmgaard, Jørgen: Den "forsvundne" produktivitet: en analyse afJ. P. Jacobsens Niels Lyhne. Poetik; 1971, 4. årg. nr. 2-3, s. 122-164.

Jensen, Johs. V.: Breen. Walther, Jens: Handlingsbeskrivelse af Breen. Poetik; 1969, serie II nr. 3, s. 56-62.

Jensen, Johs. V.: Paa Memphis Station. Brandt, Per Aage: Ødipus i Memphis. Poetik; 1971,
4. årg. nr. 2-3, s. 19.1-199.

Jensen, Thit: Orkenvandring. Skovbjerg, Karen: Frigarelsens granser: en analyse af Thit Jensens roman Ørkenvandring. Kultur \& Klasse 39; 1980 , s. 45-65.

Kafka, Franz. Gemzøe, Anker: Processen i Kafkas anti-digtning. Poetik 17; 1972, 5. årg. nr. 1, s. 25-57.

Norup, Lis: Lon for djevletjeneste. Kultur \& Klasse 51; 1985, s. 62-81.

Kampmann, Christian. Syberg, Karen: Virkeligheden der voksede over hovedet: om Christian Kampmanns forfatterskab. Poetik 27; 1976, 7. årg. nr. 3, s. 5-73. (især Visse hensyn, Faste forhold, Rene linjer og Andre måder).

Kampmann, Christian: Uden navn. Hørlych Karlsen, Hugo: Realisme og realitet: - den nye virkelighed og den nye (ny) realisme. Poetik 23; 1975, 6. årg. nr. 3, s. 74-94. (Omhandler tillige Anders Bodelsen og Tage SkouHansen.)

Kirk, Hans: Fiskerne. Holmgaard, Jørgen og Ralf Pittelkow: Samfundskritik eller sjelepleje?: - Aage Henriksen og Fiskerne. Poetik; 1971, 4. årg. nr. 4, s. 1-39.

Kristensen, Tom. Hauberg Mortensen, Finn: Tre tekster af Tom Kristensen. Poetik; 1970, 3. årg. nr. 3, s. 313-321.

Mallarmé, Stéphane. Møldrup Jensen, Flemming: Modeskribent og modernist: - om camoufleringsbehovet hos Mallarmé. Kultur \& Klasse 51; 1985, s. 34-45.

Mann, Thomas: Doktor Faustus. Schou, Søren: Thomas Manns Doktor Faustus. Poetik; 1967, serie I nr. 2, s. 20-35.

Marlowe, Christopher: Doctor Faustus. Gemzøe, Anker: Faustus og historien: en sammenlignende analyse af Historia von D. Johann Fausten og Marlowe's Doctor Faustus. Poetik 22; 1974, 6. årg. nr. 2, s. 5-44.

Molière: Dom Juan. Rastier, Francois: Fortallingens flertydighed (I): (forseg pả beskrivelse af Molières Dom Juan). Poetik; 1970, 3. årg. nr. 1, s. 34-67.

Rastier, Francois: Fortellingens flertydighed (II): (forseg på beskrivelse af Molières Dom Juan). Poetik; 1970, 3. årg. nr. 2, s. 205-226.

Oehlenschläger, Adam: Baldur hin Gode. Aaby Sørensen, Poul: Om konstitueringen afden borgerlige psyke: et bevidsthedshistorisk nybrud, belyst gennem opdragelseslitteratur og romantisk 
digtning. Kultur \& Klasse 52; 1986, s. 2653.

Paludan, Jacob: Fugle omkring Fyret. Madsen, Peter: Kontinuitetens abstrakte overvindelse. Poetik; 1971, 4. årg. nr. 2-3, s. 200-215.

Plath, Sylvia: Glasklokken. Kappel, Jette, Annette Nielsen og Lise Winther-Jensen: Frygten er levende: - en analyse af Sylvia Plaths Glasklokken. Kultur \& Klasse 41; 1981, s. 35-75.

Pontoppidan, Henrik. Grodal, Torben Kragh: Klassestruktur og historiesyn $i$ nogle Pontoppidantexter. Poetik; 1971, 4. årg. nr. 2-3, s. 182-190.

Pontoppidan, Henrik: Lykke-Per. Grodal, Torben Kragh: Pontoppidans sexualgkonomi: karaktereologien i $P$ 's romaner med sarligt henblik på Lykke-Per. Poetik; 1970, 3. årg. nr. 4, s. 329-342.

Holmgaard, Jørgen: Lykken er .... en kortfattet analyse af Henrik Pontoppidans Lykke-Per. Poetik; 1971, 4. årg. nr. 1, s. 55-78.

Pontoppidan, Henrik: Nattevagt. Kaarsholm, Preben: Pontoppidans Nattevagt. Poetik 21; 1974, 6. årg. nr. 1, s. 50-68.

Grodal, Torben Kragh: Nattevagt og den socialhistoriske analyse. Poetik 21; 1974, 6. årg. nr. 1, s. 69-88.

Pontoppidan, Henrik: Ørneflugt. Grodal, Torben Kragh: Alling og orm: handlingsopbygning og verdiunivers $i$ Den grimme Alling og Ormeflugt. Poetik; 1971, 4. årg. nr. 2-3, s. 95-105.

Rabelais, Francois. Gemzøe, Anker: Dialogen og den tragiske farce - Michael Bachtins teoretiske arbejde. Poetik; 1971, 4. årg. nr. 1, s. 3-44.

Rifbjerg, Klaus: Anna (jeg) Anna. Dines Johansen, Jørgen: Ideologi - myte - écriture. Poetik; 1971, 4. årg. nr. 2-3, s. 230-242.

Rifbjerg, Klaus: Arkivet. Scou, Søren: Den slette reproduktion og den sentimentale revolte: om pàske-underet $i$ Klaus Rifbjergs Arkivet. Poetik; 1971, 4. årg. nr. 2-3, s. 216-229.

Rifbjerg, Klaus: Konfrontation. Møller, Lis: Konfrontationer: - en psykoanalytisk inspireret analyse af Klaus Rifbjergs digtsamling Konfrontation. Kultur \& Klasse 40; 1981, s. 5-35.

Schreiner, Olive. Kaarsholm, Preben: Imperialisme og masochisme $i$ Olive Schreiners romaner. Kultur \& Klasse 50; 1985, s. 67-82.

Seeberg, Peter. Nielsen, Erik: Jeg-novellen med stadigt hensyn til Peter Seeberg. Poetik; 1969, serie II nr. 3, s. 63-75.

Shakespeare: Pericles, - Som man behager, - Stormen. Grodal, Torben Kragh: Hierarki, agteskab og social forandring $i$ Shakespeare's Som man behager, Stormen og Pericles. Poetik 22; 1974, 6. årg. nr. 2, s. 45-74.

Skou-Hansen, Tage se Kampmann, Ghristian: Uden navn.

Skram, Amalie. Busk-Jensen, Lise: Psykiske strukturer i Amalie Skrams romaner. Kultur \& Klasse 39; 1980, s. 15-44.

Solsjenitsyn, Aleksander. Chauvier, Jean-Marie: Solsjenitsyn: en politisk analyse. Kultur \& Klasse 29; 1977, s. 71-128.

Politisk Revys redaktion: Solsjenitsyns sag og arbejderklassens. Kultur \& Klasse 29; 1977, s. 129-132.

Mandel, Ernest: Solsjenitsyn, stalinismen og oktoberrevolutionen. Kultur \& Klasse 29; 1977, s. 52-64.

Solsjenitsyn, Aleksander: Archipel GULag II. Medvedev, Roj: Hvor blev en million arresterede kommunister af? Archipel GULag II. Kultur \& Klasse 29; 1977, s. 65-70.

Stangerup, Helle: Gule handsker. Holmgaard, Jørgen: Gule handsker og rene hander. Poetik; 1970, 3. årg. nr. 3, s. 227-236.

Strindberg, August. Hvidt-Nielsen, Grete: Sociale utopier: - Strindbergs ideologiske ud-og afoiklinger (1879-1887). Poetik; 1971, 4. årg. nr. 2-3, s. 165-181.

Sundt, Karen: Arbeiderliv. Juncker, Beth: Kvindekamp, klassekamp og puritanisme: en analyse af Karen Sundts kolportageroman, Arbeiderliv, fra 1901. Kultur \& Klasse 42; 1982, s. 70 112.

Tibul. Juhl Jensen, Jens: Poesi og talforhold. Tibuls elegier. Poetik; 1967, serie II nr. 1, s. 87. 99.

Olesen, Karsten: Juhl Jensen eller Tibul? (Debat om Jens Juhl Jensen: Poesi og talforhold. Tibuls elegier, i Poetik 1.1.) Poetik; 1968, serie I nr. 4, s. 62-65.

Boserup, Ivan: Hvem skrev Tibul for? (Debat om Jens Juhl Jensen: Poesi og talforhold. Tibuls elegier, i Poetik I.1.) Poetik; 1968, serie I nr. 4, s. 65-67.

Juhl Jensen, Jens: Tibuls poetiske teknik - et svar til Karsten Olesen og Ivan Boserup. Poetik; 1968, serie I nr. 4, s. 67-69.

Aagaard-Mogensen, L.: Semi-matematiske 
spil med tal. (Debat om Jens Juhl Jensen: Poesi og talforhold. Tibuls elegier, i Poetik I.1.) Poetik; 1968, serie I nr. 4, s. 69-70.

Tolstoj, L. N. Lenin om Tolstoj. Poetik 21; 1974, 6. årg. nr. 1, s. 5-18.

Agger, Gunhild: Lenin, revolutionen og Tolstoj. Poetik 21; 1974, 6. årg. nr. 1, s. 19-49.

Tolstoj, L. N.: Anna Karenina. Agger, Gunhild: Mellem jorden og jernet: en analyse af $L . N$. Tolstojs Anna Karenina. Kultur \& Klasse 37; 1980, s. 89-120.

Wallraff, Günter. Negt, Oskar: Wallraffs undersagelsesarbejde i den "tilslorede virkeligheds" regioner, 1975. Kultur \& Klasse 36; 1979, s. 78-103.

Zola, Emile: Les Rougon-Macquart. Lund Nielsen, Jens Peter: Klassekampens fysiologi $i$ Les Rougon-Macquart. Poetik; 1970, 3. årg. nr. 2, s. 108-129.

Aakjar, Jeppe. Zerlang, Martin: Fra land til by med Jeppe Aakjar og Nick Carter: signalement af arbejderlitteraturen omkring 1900. Kultur \& Klasse 38; 1980, s. 26-49.

Aakjar, Jeppe: Vredens Born. Svane, MarieLouise: Social kritik og folkelig tradition $i$ Aakjers roman Vredens Bern. Kultur \& Klasse $38 ; 1980$, s. 6-25.

\section{Litteraturkritik/-videnskab}

Wille, Niels Erik: Kritik, padagogik og videnskab. Poetik; 1967, serie I nr. 1, s. 6-16.

Brandt, Per Aage: Den ny kritik i Frankrig: en introduktion. Poetik; 1968, serie I nr. 3, s. 810.

Andersen, Hans Jørgen: Et ideologisk perspektiv $i$ den franske ny-kritik. Poetik; 1968, serie I nr. 3, s. 11-25.

Brandt, Per Aage: En ren kritik? Poetik; 1968, serie I nr. 3, s. 56-71.

Egebak, Jørgen, Peter Madsen og Helle Munk Thygesen: Målsainingsdebat. Poetik; 1968, serie I nr. 4, s. 51-61.

Jansen, Steen: Målsetningsdebat I. Poetik; 1969, serie II nr. 1, s. 84-90.

Rodwell, Hugh: Malssiningsdebat II: the dilemma of Bourgeois Criticism. Poetik; 1969, serie II nr. 1, s. 91-92.

Bang, Jørgen: Litteraturkritikkens perspektiv. Poetik; 1969, serie II nr. 2, s. 39-43.

Madsen, Peter: Strukturalistisk litteraturviden- skab - kritisk videnskab eller hvad berer teksten?. Poetik 17; 1972, 5. årg. nr. 1, s. 58-77.

Madsen, Peter: Modsigelsens poetik. Poetik 18; 1972, 5. årg. nr. 2, s. 174-208.

Madsen, Peter: Litteraturvidenskab og socialvidenskab: til ideologi-analysens socialvidenskabelige begrundelse. Poetik 19; 1973, 5. årg. nr. 3, s. 111-132.

Baggesen, Søren: Litteraturhistorikerens problem som traditionsberer: - et arbejdspapir. Kultur \& Klasse 32; 1978, s. 18-31.

Grodal, Torben Kragh: Efterskrift. Kultur \& Klasse 32; 1978, s. 115-128.

Fjord Jensen, Johan: Efter Guldalderkonstruktionens sammenbrud. Kultur \& Klasse 35; 1979, s. 11-37.

Bækholm, Rigmor: Introduktion til en engelsk tradition. Kultur \& Klasse 35; 1979, s. 5466.

Behrendt, Poul: Tekst, historie og samfund: om forholdet mellem teori og praksis hos Jergen Bonde Jensen, hos Villy Serensen - og i den kritiske videnskab. Kultur \& Klasse 35; 1979, s. 92145.

\section{Litteratursociologi}

Iversen, Irene: Grunnlaget for en litteratursosiologi. Poetik; 1969, serie II nr. 1, s. 5-18.

Aspelin, Kurt: Om konsten att bortse frän motsättningar: några synspunkter på "empirio-positivistisk kultur- och litteratursociologi. Poetik 20; 1972-1973, 5. årg. nr. 4, s. 3-15.

Madsen, Peter: Kritikken af den politiske økonomi og /litteratursociologiu. Poetik 20; 1972-1973, 5. årg. nr. 4, s. 16-34.

Sørensen, Peer E.: Uddrag af arbejdspapir om litteratursociologi: om kunstverket $i$ cirkulationen. Poetik 20; 1972-1973, 5. årg. nr. 4, s. 45-62.

Melberg, Arne: Introduktion til århundredeskiftet og tierne. Poetik24; 1975, 6. årg. nr. 4, s. 4355.

Furuland, Lars: Litteraturen i samhällsdebatten: kommentarer till några forskningsresultat inom svensk litteratursociologi. Kultur \& Klasse 42; 1982, s. 45-60.

Zerlang, Martin: Historien og de gode historier. Kultur \& Klasse 50; 1985, s. 23-34. 


\section{Massekommunikation}

Lykke Knudsen, Nils: Reklame og mening. Poetik; 1971, 4. årg. nr. 4, s. 56-71.

Giersing, Morgen: Massekommunikation. Kultur \& Klasse 36; 1979, s. 5-6.

Grodal, Torben Kragh: Udviklingstendenser og problemer i fremtidens mediestruktur. Kultur \& Klasse 36; 1979, s. 7-18.

Mattelart, Armand: Kulturimperialisme $i$ de multinationales tidsalder. Kultur \& Klasse 36; 1979, s. 33-56.

Ørvad Andersen, Lizzie: En autoriter padagogik: analyse af seriehaftet Den store Kanon. Kultur \& Klasse 36; 1979, s. 57-77.

Negt, Oskar: Wallraffs undersegelsesarbejde $i$ den stilslerede virkeligheds" regioner, 1975. Kultur \& Klasse 36; 1979, s. 78-103.

Andersen, Tine: Omkring Else Kant. Kultur \& Klasse 39; 1980, s. 102-112.

Liebst, Asger: Småborgeren og skandalen: - skandalepresse og smäborgerlig socialkarakter $i$ 1830'emes Kabenhavn. Kultur \& Klasse 46; 1982, s. 83-100.

Kaarsholm, Preben: Imperialisme som fin-desiècle modernisme: engelsk unew journalism" $i$ 1890 'eme. Kultur \& Klasse $51 ; 1985$, s. 4661.

\section{Mentalitetshistorie se Bevidstheds- historie/mentalitetshistorie}

\section{Musik}

Nielsen, Poul: Kommentar til Per Aage Brandts artikel Strukturalisme på empirisk grundlag i Poetik I.l. Poetik; 1967, serie I nr. 2, s. $76-$ 80.

Brandt, Per Aage: Debat - Svar til Poul Nielsen. Poetik; 1967, serie I nr. 2, s. 80-81.

Nielsen, Poul: Debat - Svar til Per Aage Brandt. Poetik; 1967, serie I nr. 2, s. 81-82.

Nielsen, Elo: Narcissisme og beatmusik. Kultur \& Klasse 30; 1977, s. 85-105.

Møller, Hanne: Kvindesange. Kultur \& Klasse 39; 1980, s. 113-127.

Schou, Søren: Da friheden kom til K. B. Hallen: Don Redman-koncerten 1946. Kultur \& Klasse 50; 1985, s. 83-93.

Overgaard Gotthardsen, Mette: Dremmebille- der: et forsag til en psyko-social tolkningsmodel for H. C. Lumbyes musik $i$ Tivoli omkring midten af 1800-tallet. Kultur \& Klasse 51; 1985, s. 8-33.

\section{Narratologi}

Dines Johansen, Jørgen: Det fortaltes struktur. Poetik; 1967, serie I nr. 2, s. 55-75.

Greimas, Algirdas-Julien: Grundtrek af en narrativ grammatik. Poetik; 1969, serie II nr. 3, s. 1-21.

Mønster Pedersen, Jørgen og Per Aage Brandt: Narratologiske noter. Poetik; 1969, serie II nr. 3, s. 22-37.

Madsen, Peter: Det integrerede normbrud: narratologisk analyse. Poetik; 1970, 3. årg. nr. 1, s. 1-20.

Beck Nielsen, Steen og Lars Fuglsang: Fredric Jameson og den historiske udvikling af det narrative. Kultur \& Klasse 49; 1984, s. 62-93.

\section{Psykologi}

Walther, Jens: Handlingsbeskrivelse på grundlag af den dynamiske psykologi. Poetik; 1969, serie II nr. 3, s. 44-55.

Gunder Hansen, Nils: Subjektets civilisering: en introduktion til Norbert Elias' historiske psykologi. Kultur \& Klasse 38; 1980, s. 50-78.

Andkjær Olsen, Ole: Omkring Lacan/Laplanche-kontroversen: introduktion til Jean Laplanche: Sproget og det ubevidste. Kultur \& Klasse 47 ; 1983, s. 7-31.

Laplanche, Jean: Sproget og det ubevidste. Kultur \& Klasse 47; 1983, s. 33-71.

Møller, Lis: Der Sandmann og Freuds analyse af fortellingen i Das Unheimliche: - et essay om psykoanalyse og tekstanalyse. Kultur \& Klasse 47; 1983, s. 73-89.

Schorske, Carl E.: Politik og fadermord i Freuds Dremmetydning. Kultur \& Klasse 49; 1984, s. 8-33.

Schantz Lauridsen, Palle: Kvernen kan ikke standses: fantasiens fabel. Kultur \& Klasse 49 ; 1984, s. 94-115.

\section{Pedagogik se Uddannelse og pe- dagogik}




\section{Semiotik/semiologi og semantik}

Olesen, Karsten R.: Semantiske strukturmodeller. Poetik; 1968, serie I nr. 3, s. 26-55.

Toft, Jens: Filmsemiologi. Poetik; 1968, serie I, nr. 4, s. 5-16.

Brandt, Per Aage: Fiktivitet og semiologi. Poetik; 1969, serie II nr. 2, s. 44-59.

Siggaard Jensen, Hans: Om logik, semantik og litteraturvidenskab. Poetik; 1969, serie II nr. 2, s. 60-66.

Greimas, Algirdas-Julien: Grundtrek af en narrativ grammatik. Poetik; 1969, serie II nr. 3, s. $1-21$.

Toft, Jens: Filmteori og filmanalyse. Poetik; 1969, serie II nr. 3, s. 38-43.

Mønster Pedersen, Jørgen: Skriftens tre-uenighed. Poetik; 1970, serie II nr. 4, s. 51-54.

Sørensen, Hans: Begrebet diakroni inden for litteraturforskningen. Poetik; 1970, serie II nr. 4 s. 77-79.

Madsen, Peter: Det integrerede normbrud: narratologisk analyse. Poetik; 1970, 3. årg. nr. 1, s. $1-20$.

Reder, Viggo: Om Propp's Morphology of the Folktale. Poetik; 1970, 3. årg. nr. 1, s. 21-33.

Toft, Jens: Analyse af Picasso: Portret af en ung kvinde (Sylvette), 1954. Poetik; 1970, 3. årg. nr. 1, s. 73-78.

Kjørup, Søren: Om forskellen mellem de konventionelle og de såkaldt naturlige tegn. Poetik; 1970, 3. ărg. nr. 1, s. 79-86.

Brandt, Per Aage: Barthes og den semiologiske model. Poetik; 1970, 3. årg. nr. 1, s. 87-95.

Mønster Pedersen, Jørgen: Udviskning af en metafysik: på vej mod en generel numismatik. Poetik; 1970, 3. årg. nr. 3, s. 277-291.

Brandt, Per Aage: Seksualitet og tekstualitet/Color love 3. Poetik; 1970, 3. årg. nr. 3, s. 292296.

Brandt, Per Aage: En sang om mennesket og magten. Poetik; 1970, 3. årg. nr. 4, s. 323-328.

Pittelkow, Ralf: Om litteratur som socialt fanomen (semiologiske noter). Poetik; 1970, 3. årg. nr. 4, s. 343-361.

Holmgaard, Jørgen: Introduktion til numismatikken. Poetik; 1970, 3. årg. nr. 4, s. 363-381.

Andkjær Olsen, Ole: Om gkonomiens teori og teoriens akonomi: bidrag til konsumtionens semiotik. Poetik; 1971, 4. årg. nr. 4, s. 72-85.

Brask, Peter: Semantiske beskrivelses-principper: eksempler på nytlen af algebraiske grupper ved beskrivelse af betydningsfelter. Poetik 17; 1972, 5. årg. nr. 1, s. 78-117.

Schantz Lauridsen, Palle: Kvornen kan ikke standses: fantasiens fabel. Kultur \& Klasse 49; 1984, s. 94-115.

\section{Skolelererlitteratur}

Zerlang, Martin: Skolelarerlitteraturen 18601900. Kultur \& Klasse 33; 1978, s. 8-81.

Nielsen, Anton: Hyrdedrengen. Kultur \& Klasse $33 ; 1978$, s. $82-90$.

Egebjerg, Edvard: Der er et yndigt Land. Kultur \& Klasse 33; 1978, s. 91-101.

\section{Skonlitterere forfatterskaber se Litteraturanalyser og skønlittere- re forfatterskaber}

\section{Socialisationsteori}

Reitan, Rolf og Carsten Thau: Interview med Peter Brückner. Kultur \& Klasse 30; 1977, s. 7-22.

Karol, K. S.: Interview med Michel Foucault. Kultur \& Klasse 30; 1977, s. 23-35.

Fausing, Bent: Estetik, kommunikation, socialisation. Kultur \& Klasse 30; 1977, s. 36-84.

Nielsen, Elo: Narcissisme og beatmusik. Kultur \& Klasse 30; 1977, s. 85-105.

\section{Sprogteori}

Brask, Peter: Om logiske konstruktions-forskelle mellem "talesprog" og "skriftsprog" - et metodeexempel. Poetik; 1969, serie II nr. 1, s. 19 31.

Andkjær Olsen, Ole: Omkring Lacan/Laplanche-kontroversen: introduktion til Jean Laplanche: Sproget og det ubevidste. Kultur \& Klasse 47; 1983, s. 7-31.

Laplanche, Jean: Sproget og det ubevidste. Kultur \& Klasse 47; 1983, s. 33-71.

\section{Strukturalisme}

Brandt, Per Aage: Strukturalisme på empirisk grundlag. Poetik; 1967, serie I nr. 1, s. 17 47.

Nielsen, Poul: Kommentar til Per Aage Brandts 
artikel Strukturalisme på empirisk grundlag i Poetik 1.1. Poetik; 1967, serie I nr. 2, s. 7680.

Brandt, Per Aage: Debat - Svar til Poul Nielsen. Poetik; 1967, serie I nr. 2, s. 80-81.

Nielsen, Poul: Debat - Svar til Per Aage Brandt. Poetik; 1967, serie I nr. 2, s. 81-82.

Dines Johansen, Jørgen: Karakter og handling: overvejelser over Aristoteles' poetik. Poetik; 1968, serie I nr. 4, s. 17-24.

Madsen, Peter: Noter om Aristoteles' poetik. Poetik; 1968, serie I nr. 4, s. 25-35.

Brandt, Per Aage: Matematik og metaforik. Poetik; 1968, serie I nr. 4, s. 71-72. (Debat om P. A. Brandt: Strukturalisme på empirisk grundlag i Poetik I.1.)

Brask, Peter: Om logiske konstruktions-forskelle mellem "talesprog" og "skriftsprog" - et metode-exempel. Poetik; 1969, serie II nr. 1, s. 1931.

Grodal, Torben Kragh: Koharens sandsynlighed vurdering - debat. Poetik; 1969, serie II nr. 2, s. 67-72. (Debat om Peter Madsen: Noter om Aristoteles' poetik, i Poetik I.4.)

Brandt, Per Aage: Greimas og videnskabelighedens struktur. Poetik; 1969, serie II nr. 3, s. 91-93.

Pittelkow, Ralf: Skitse til en handlingsmodel. Poetik; 1970, serie II nr. 4, s. 4-20.

Egebak, Jørgen: "Historismer og "strukturalismer. (Debat.) Poetik; 1970, serie II nr. 4, s. 55-70.

Romhild, Lars Peter: Kommentar til Jorgen Egebak: "Historisme" og "strukturalisme". Poetik; 1970, serie II nr. 4, s. 71-73.

Madsen, Peter: Debat. (Kommentar til Jørgen Egebak: "Historisme« og »strukturalisme«.) Poetik; 1970, serie II nr. 4, s. 74-76.

Pittelkow, Ralf: Marxisme og strukturalisme: en introduktion til Lucien Sebag. Poetik; 1970, 3. årg. nr. 3, s. 297-312.

Brandt, Per Aage, Peter Madsen og Ralf Pittelkow: Kritik af en ukritisk kritik. (Debat.) Poetik; 197l, 4. årg. nr. 1, s. 9l-99.

\section{Tekstteori}

Kock, Christian: Literaritet. Poetik; 1969, serie II nr. 1, s. 32-47.

Brandt, Per Aage: Tekstens teori. Poetik; 1970, serie II nr. 4, s. 21-50. van Dijk, T. A.: Nogle aspekter af en generativ transformationel tekstteori. Poetik; 1970, 3. årg. nr. 2, s. 155-177.

Kock, Christian: Bemerkninger til en textteori: forsog $i$ retning afflere kriterier for textbeskrivelse. Poetik; 1970, 3. årg. nr. 2, s. 178-204.

Bostrup, Lars, Peter Brask og Carsten Hansen: Leserens gestaltning af en litterer tekst. Poetik; 1970, 3. årg. nr. 3, s. 237-250.

Brandt, Per Aage: Skriftens nulpunkt og den store blafren. Poetik; 1971, 4. årg. nr. 1, s. 45-54.

Grodal, Torben Kragh: Tematisk tekstanalyse: en skitsering af tekstanalytisk emneområde. Poetik; 1971, 4. årg. nr. 4, s. 40-55.

Røder, Viggo: Textens grenser. Poetik 18; 1972, 5. årg. nr. 2, s. 209-222.

Pittelkow, Ralf: Samfundsteori og tekstteori. Poetik 19; 1973, 5. årg. nr. 3, s. 5-73.

Barthes, Roland: Fra vark til tekst. Kultur \& Klasse 40; 1981 , s. $36 \times 43$.

\section{Uddannelse og padagogik}

Brandt, Per Aage: Om dannelsen, uddannelsen og omdannelsen. Poetik; 1970, 3. årg. nr. 4, s. 415-421.

Brask, Peter: Känon, doktrin og historieforfalskning: et eksempel fra gymnasiets danske teksttradition. Poetik; 1971, 4. årg. nr. 2-3, s. 6573.

Hougaard, Jens: Dansk $i$ historien. Kultur \& Klasse 35; 1979, s. 146-160.

Frederiksen, Lise Lotte: Ungdom og barndom: metodiske problemer omkring historisk-tematisk lesning i gymnasiet og på HF. Kultur \& Klasse $35 ; 1979$, s. 161-173.

Lindhardtsen, Jytte: Norm og afvigelse. Kultur \& Klasse 35 ; 1979, s. 174-188.

Harrebye, Leif og Johan Rosdahl: Temalesning og elevsituation. Kultur \& Klasse 35; 1979, s. 189-197.

Grodal, Torben Kragh: Frihed og nodvendighed: betragtninger over litteraturens og litteraturundervisningens funktioner. Kultur \& Klasse 38; 1980, s. 97-109.

\section{Videnskabelige forfattere}

Adorno, Theodor W. Secher, Claus: Kunsten og den forvaltede verden: en analyse af Theodor $W$ Adornos astetiske teori og litteraturkritiske prak- 
sis. Poetik 18; 1972, 5. årg. nr. 2, s. 133-173. Mjöset, Lars: Forlösningens antinomier: utkast om forholdet mellem Benjamin og Adorno. Poetik 28; 1976, 7. årg. nr. 4, s. 55-103.

Aristoteles. Dines Johansen, Jørgen: Karakter og handling: overvejelser over Aristoteles' poetik. Poetik; 1968, serie I nr. 4, s. 17-24.

Madsen, Peter: Noter om Aristoteles' poetik. Poetik; 1968, serie I nr. 4, s. 25-35.

Bachtin, Michael. Gemzøe, Anker: Dialogen og den tragiske farce - Michel Bachtins teoretiske arbejde. Poetik; 1971, 4, årg. nr. 1, s. 3-44.

Barthes, Roland. Brandt, Per Aage: Barthes og den semiologiske model. Poetik; 1970, 3. årg. nr. 1, s. 87-95.

Benjamin, Walter. Kirkegaard, Peter: Lille receptionshistorie: indledning til Harald Steinhagen: Om Walter Benjamins allegoribegreb. Kultur \& Klasse 47; 1983, s. 91-94.

Steinhagen, Harald: $O m$ Walter Benjamins allegoribegreb. Kultur \& Klasse 47; 1983, s. 95-117.

Benjamin, Walter, se også Adorno, T. W. (Mjöset).

Brecht, Bertolt. Bondebjerg, Ib: Bertolt Brecht. Ideologikritiker og proletarisk praktikant: om litteraturteori og -praksis hos Brecht og ansatserne til en proletarisk kulturteori $i$ Sorjetunionen og Tyskland i mellemkrigstiden. Poetik 25; 1975, 7. årg. nr. 1, s. 38-115.

Brückner, Peter. Reitan, Rolf og Carsten Thau: Interview med Peter Brückner. Kultur \& Klasse $30 ; 1977$, s. 7-22.

Foucault, Michel. Karol, K. S.: Interview med Michel Foucault. Kultur \& Klasse 30; 1977, s. 23-35.

Freud, Sigmund. Schorske, Carl E.: Politik og fadermord i Freuds Drommetydning. Kultur \& Klasse 49; 1984, s. 8-33.

Ginzburg, Carlo. Zerlang, Martin: Karneval og katterbål: introduktion til Carlo Ginzburgs forfatterskab. Kultur \& Klasse 40; 1981, s. 7394.

Goux, J.-J. Holmgaard, Jørgen: Introduktion til numismatikken. Poetik; 1970, 3. årg. nr. 4, s. 363-381.

Greimas, Algirdas-Julien. Brandt, Per Aage: Greimas og videnskabelighedens struktur. Poetik; 1969, serie II nr. 3, s. 91-93.

Henningsen, Poul. Madsen, Peter: Radikalisme og humanisme - : to kapitler om dansk ideologi. Kultur \& Klasse 34; 1979, s. 9-43.

Jameson, Fredric. Beck Nielsen, Steen og Lars Fuglsang: Fredric Jameson og den historiske udvikling af det narrative. Kultur \& Klasse 49; 1984, s. 62-93.

Kierkegaard, Seren. Avlund Frandsen, Hans Erik: Historieproblemet hos Kierkegaard og den unge Marx. Poetik 26; 1975, 7. årg. nr. 2, s. 7-90.

Lacan, Jacques. Andkjær Olesen, Ole: Omkring Lacan/Laplanche-kontroversen: introduktion til Jean Laplanche: Sproget og det ubevidste. Kultur \& Klasse $47 ; 1983$, s. 7-31.

Laplanche, Jean se Lacan, Jacques.

Lenin, V. I. Agger, Gunhild: Lenin, revolutionen og Tolstoj. Poetik 21; 1974, 6. årg. nr. I, s. 19-49.

Lukács, Georg. Giersing, Morten: Lukács som litteraturkritiker. Poetik 28; 1976, 7. årg. nr. 4, s. 6-54.

Feher, Ferenc: Lukács i Weimar: Georg Lukács' klassicisme og hans realismeteori. Kultur \& Klasse 37; 1980, s. 43-75.

Busk-Jensen, Lise: Bristede illusioner: om klassekampen i Balzacs roman Bristede illusioner (1837-1843) og konsekvenserne af dens fravar i Lukács' analyse (fra 1935). Kultur \& Klasse 37; 1980, s. 76-88.

Kaarsholm, Preben: Lukács, kulturen og muligheden af et andet liv: fra Sondagskredsen til de flyvende universiteter. Kultur \& Klasse 45; 1982, s. 7-23.

Márkus, György: Sjelen og livet: den unge Lukács og »kultur"-problemet. Kultur \& Klasse 45; 1982, s. 24-48.

Lukács, Georg. Heller, Agnes: Den eldre Lukács filosofi. Kultur \& Klasse 45; 1982, s. 55-70.

Löwenthal, Leo. Gudmundsson, Halldor: Ideologikritik og tradition: om Leo Löwenthals litteraturanalyser. Kultur \& Klasse 49; 1984, s. 34-61.

Marx, Karl se Kierkegaard, Søren.

Propp, Vladimir. Røder, Viggo: Om Propp's Morphology of the Folktale. Poetik; 1970, 3. årg. nr. 1, s. 21-33.

Sartre, Jean-Paul. Rossanda, Rossana: Sartre og den politiske praksis. Kultur \& Klasse 34; 1979, s. 70-103.

Sebag, Lucien. Pittelkow, Ralf: Marxisme og 
strukturalisme: en introduktion til Lucien Sebag. Poetik; 1970, 3. årg. nr. 3, s. 297-312.

Thompson, E. P. Kaarsholm, Preben: Engelske excentrikere: E. P. Thompson, The Poverty of Theory og den engelske althusserianisme. Kultur \& Klasse $43 ; 1982$, s. $5-41$.
Thomson, George. Kaarsholm, Preben, George Thomson og antikken: om nogle livtag med den historiske materialisme. Poetik 22; 1974, 6. årg. nr. 2, s. 146-189.

\section{Estetik se Kunstteori og estetik}

\section{Anmeldelser}

Adorno, Theodor W.: Kierkegaard, Konstruktion des ästhetischen. Thübingen: Verlag von J. C. Mohr, 1933 (da. udg.: Rhodos, 1980). (Walter Benjamin: Kierkegaard: - den filosofiske idealismes afslutning.) Kultur \& Klasse $40 ; 1981$, s. $95-96$.

Ariès, Philippe: Bamdommens historie. Kbh.: Nyt Nordisk Forlag, 1982. (Martin Zerlang: Overklassebarndommens historie.) Kultur \& Klasse 48; s. 129-131.

Bayerdörfer, Hans-Peter: Poetik als sprachtheoretisches Problem. Tübingen: Max Niemeyer Verlag; 1967. (Chr. Kock.) Poetik; 1969, serie II nr. 1, s. 96.

Berman, Marshall: All That Is Solid Melts Into Air. The Experince of Modernity. New York: Simon and Schuster, 1982. (Lars Dybdahl: Digterens glorie $i$ gadens malstrom.) Kultur \& Klasse 51; 1985, s. 120-126.

Bonde Jensen, Jørgen: Litterar arkeologi. Studier $i$ Villy Sarensens Formynderfortellinger. Kbh.: Gyldendal, 1978. (Søren Schou: Villy Sorensens aktualitet.) Kultur \& Klasse 34; 1979, s. 104-112.

Bonde Jensen, Jørgen: Replik til Soren Schou. Kultur \& Klasse 34; 1979, s. 113-116.

Bondebjerg, Ib: Proletarisk offentlighed, bd. 1. Kbh.: Medusa, 1976. (Lars Mjöset: Kulturradikalisme?) Kultur \& Klasse $31 ; 1977$, s. 120-128.

Bondebjerg, Ib: Proletarisk offentlighed, bd. 2 se Bondebjerg, Ib og Olav Harsløf (red.): Arbejderkultur 1924-48.

Bondebjerg, Ib og Olav Harsløf (red.): Arbejderkultur 1924-48. Kbh.: Medusa, 1979 og Bondebjerg, Ib: Proletarisk offentlighed 2. Kbh.: Medusa, 1980. (Hans Erik Avlund Frandsen et al.: Arbejderbevidsthed og arbejderkultur $i$ mellemkrigstiden.) Kultur \& Klasse 42; 1982, s. 113-123.
Borgnakke, Karen et al.: Pomografi. Kbh.: Munksgård, 1974. (Finn Storgård.) Poetik $25 ; 1975,7$. årg. nr. 1, s. 168-171.

Brandt, Mariann, Jan Graulund og Dorthe Wendt: Socialdemokratisk agitation og propaganda $i$ mellemkrigstiden. Århus: Skansen: i kommission hos Fagtryk, 1979. (Bent Fausing: Kilden empiri.) Kultur \& Klasse 42; 1982, s. 133-137.

Bredsdorff, Thomas: Tristans born. Kbh.: Gyldendal, 1982. (Niels Gunder Hansen.) Kultur \& Klasse 46; 1982, s. 103-106.

Bryld, Mette og Nina Lykke (red.): Kvindespor $i$ videnskaben. Odense: Odense Universitetsforlag, 1985. (Marie-Louise Svane: Hvor forer sporene hen?') Kultur \& Klasse 52; 1986, s. 74-80.

Busk-Jensen, Lise: Frigørelse eller selvrealisering. Analyser $i$ George Sands feministiske forfatterskab 1832-44. Kbh.: C. A. Reitzel, 1981. (Brynja Svane: George Sands feministiske utopi.) Kultur \& Klasse 46; 1982, s. 107-109. Castaneda, Carlos: The Teachings of Don Juan, a yaqui way of knowledge. Fulton: University of California Press, 1968. (H. Siggaard Jensen.) Poetik; 1969, serie II nr. 2, s. 66.

Christensen, Erik M.: Verifikationsproblemet ved litteraturvidenskabelig meningsanalyse. Odense: Odense University Press, 1971. (Niels Ole Finnemann: Kritiske bemarkninger til Erik $M$. Christensens erkendelsesforsag.) Poetik 18; 1972, 5. årg. nr. 2, s. 223-235.

Christensen, Hans Jørn: Trivialmyter. En genreanalyse. Århus: Forlager GMT, 1974. (GMTs serie »Pædagogiske arbejdsmapper). (Bent Fausing: Forskning og padagogik. Trivialmyter.) Poetik 25; 1975, 7. årg. nr. 1, s. 165-167.

Dahlerup, Pil: Det modeme gennembruds kvinder. Kbh:: Gyldendal, 1984. (Torben Kragh 
Grodal.) Kultur \& Klasse 49; 1984, s. 116126.

Dalager, Stig og Anne-Marie Mai: Lenin og kulturen. Om Lenins kulturopfattelse. Århus: Forlaget Arkona, 1978. (Anker Gemzøe: Lenin som kulturmonument.) Kultur \& Klasse 37; 1980, s. 121-125.

Dalager, Stig og Anne-Marie Mai: Replik. Kultur \& Klasse 42; 1982, s. 138-141. (Om Lenin og kulturen.)

Gemzøe, Anker: Duplik. Kultur \& Klasse 42; 1982, s. 142-143. (Om Lenin og kulturen.)

Dines Johansen, Jørgen: Hvaleme venter. Studier i Klaus Rifbjergs forfatterskab. Odense: Odense Universitetsforlag, 1981. (Lis Møller: Uskyld og dod.) Kultur \& Klasse 45; 1982, s. 103-106.

Donzelot, Jacques: La police des familles. Paris: Les Editions de Minuit, 1977. (eng. overs.: The policing of Families. N. Y.: Pantheon Books, 1979). (Simo Koppe: Familiernes politi.) Kultur \& Klasse 47; 1983, s. 125-128.

Eagleton, Terry: Walter Benjamin, or Towards a Revolutionary Criticism. London: New Left Books, 1981. (Christen Kold Thomsen: Benjamin $i$ engelsk belysning.) Kultur \& Klasse $45 ; 1982$, s. 99-102.

Engelstad, Irene: Sammenbrudd og gjennombrudd. Oslo: Pax, 1984. (Lise Busk-Jensen: Amalie Skram og kvindernes problemer.) Kultur \& Klasse 52; 1986, s. 68-74.

Engelund, Claus, Ronald Gernskov og Lis Tanghøj: Om Hans Kirks Daglejerne og De ny Tider. Kbh.: Litteratur og Samfund, 1979. (Leif Emerek: Arbejde og dagligt brod.) Kultur \& Klasse 42; 1982, s. 124-132.

Erslev Andersen, Jørgen, Hans-Jørgen Schanz og Per Stounbjerg (red.): Det moderne - en bog om Jürgen Habermas. Århus: Modtryk, 1983. (Arno Victor Nielsen: $\mathrm{DaHa}$ bermas blev moderne.) Kultur \& Klasse 51; 1985, s. 118-120.

Fausing, Bent og Peter Larsen (red.): Visuel kommunikation, bd. 2. Kbh.: Medusa, 1980. (Jørn Guldberg: Billedanalysen og historien.) Kultur \& Klasse 44; 1982, s. 88-99.

Fiil, Steen et al.: Bondeoffentlighed i Danmark i det 19. århundrede. Århus: Fagtryk, 1975. (Henrik Reinvaldt: Bondeoffentlighed uden bander.) Kultur \& Klasse 33; 1978, s. 112-118.
Fjord Jensen, Johan: Efter guldalderkonstruktionens sammenbrud, I-III. Århus: Modtryk, 1981. (Anker Gemzøe: Udvikling og kritikken.) Kultur \& Klasse 47; 1983, s. 129-137. Gleerup, Jørgen og Povl Schmidt (red.): Dansk kulturhistorie og bevidsthedsdannelse 1880-1920. Odense: Odense Universitetsforlag, 1976 ff. (Martin Zerlang.) Kultur \& Klasse $33 ; 1978$, s. 119-126.

Goodman, Nelson: Languages of Art - An Approach to a Theory of Symbols. Indianapolis/ New York: Bobbs-Merrill Company, 1968. (Søren Kjørup: Introduktion - Nelson Goodman og hans bog om kunst, sprog og kunstsprog.) Poetik; 1970, 3. årg. nr. 1, s. 96-103.

Hanneborg, Knut: The Study of Literature. Oslo: Universitetsforlaget, 1967. (Per Aage Brandt et al.: Mellem filosofi og litteraturvidenskab.) Poetik; 1968, serie I nr. 4, s. 3650.

Hansen, Børge: Folkeeventyr, struktur og genre. Kbh.: Munksgaard, 1971. (Viggo Røder: Subjekt, eventyr og narratologi.) Poetik 17; 1972, 5. årg. nr. 1, s. 128-131.

Hansen, Erik og Harald Steensig (under medvirken af Ester Herlak): Dansk er mange ting. Kbh.: Gjellerup, 1968 (N.E.W.). Poetik; 1968, serie I nr. 4, s. 73.

Hauser, Arnold: Kunstens og litteraturens socialhistorie I-II. Kbh.: Bibliotek Rhodos, 1980. (Else Marie Bukdahl: Kunsthistorien og den marxistiske sociologi.) Kultur \& Klasse $44 ; 1982$, s. 80-87.

Hirsch, E. D.: Validity in Interpretation. New Haven \& London: Yale University Press, 1967. (N.E.W.) Poetik; 1968, serie I nr. 4, s. 73.

Hjordt-Vetlesen, Inger-Lise: Flugtens fengsel. Odense: Odense Universitetsforlag, 1981. (Dan Nissen: Aakjer mellem land og by.) Kultur \& Klasse 46; 1982, s. 110-113.

Holland, Norman N.: The Dymamics of Literary Response. New York: Oxford University Press, 1968. (Chr. Kock.) Poetik; 1969, serie II nr. 1, s. 95.

Ingarden, Roman: Vom Erkennen des literarischen Kunstwerks. Darmstadt: Wissenschaftliche Buchgesellschaft, 1968. (Chr. Kock.) Poetik; 1969, serie II nr. 1, s. 95.

Juncker, Beth: Kuinder, klasser og ugeblade. Kbh.: Medusa, 1976. (Åse Lading: Ideologi 
og virkelighedsoplevelse.) Kultur \& Klasse 30; 1977 , s. 106-111.

Jørgensen, John Chr.: At lese forfatterskab. Kbh.: Borgen, 1974. (Søren Schou: John Chr. Jergensens forfatterskabs-bog.) Poetik 25; 1975, 7. årg. nr. 1, s. 155-159.

Jørgensen, John Chr.: Litterar metodelare. Kbh.: Borgen, 1971. (Peter Madsen: Advarsel mod en institution.) Poetik 17; 1972, 5. årg. nr. 1, s. 118-126.

Jørgensen, John Chr.: Forsvar for en bog. Poetik 17; 1972, 5. årg. nr. 1, s. 126-127. (Om Litterer metodelare.)

Kastholm Hansen, Claes: Den kontrollerede virkelighed. Kbh.: Akademisk Forlag, 1976. (Lise Busk-Jensen og Tine Andersen: Den fortrangte virkelighed). Kultur \& Klasse 30; 1977 , s. 112-125.

Kock, Walter A.: Vom Morphem zum Textem/ From Morpheme to Texteme. Hildesheim: Olms Paperbacks, 1969. (C.K.) Poetik; 1970, 3. årg. nr. 3, s. 322.

Kyndrup, Morten: Astetik og litteratur. "Fodboldenglen " - dens modtagelse og estetik. Århus: Arkona, 1982. (Søren Schou: Estetik er flere ting.) Kultur \& Klasse 47; 1983, s. 139-142.

Langages 10. (red.): Greimas, A. J.: Pratiques et langages gestuels. Paris: Larousse, juni 1968. (PAaB.) Poetik; 1968, serie I nr. 4, s. 73-74.

Langages 17. (red.): Todorov, Tzvetan: L'enonciation. Paris: Larousse, marts 1970. (C.K.) Poetik; 1970, 3. årg. nr. 3, s. 322.

Leech, Goeffrey N.: A linguistic Guide to English Poetry. London: Longman's, 1969. (C.K.) Poetik; 1970, 3. årg. nr. 3, s. 322.

Metz, Christian: Essais sur la signification au cinema. Paris: Editions Klinksieck, 1968. (Jens Toft.) Poetik; 1969, serie II nr. 2, s. 72.

Myers, Henry Alonzo: Systematic Pluralism. A Study in Metaphysics. Ithaka, N.Y.: Cornell University Press, 1961. (PAaB.) Poetik; 1969, serie II nr. 1, s. 93.

Mylius, Johan de: Myte og roman. Kbh.: Gyldendal, 1981. (Jørgen Holmgaard: Driften mod mytens enhed $-i$ disputatsform.) Kultur \& Klasse 43; 1982, s. 81-84.

Møller Kristensen, Sven: Vurderinger. 3. opl. Kbh.: Gyldendal, 1968. (PAaB.) Poetik: 1969, serie II nr. 1, s. 93-94.

Nielsen, Erik A.: Holbergs komik. Kbh.: Gyldendal, 1984. (Jens Kr. Andersen: Historie eller analogi?') Kultur \& Klasse 52; 1986, s. 54-65.

Piaget, Jean: Le structuralisme. Que sais-je? Paris: Presses Universitaires de France, 1968. (da. overs. Reitzels forlag, 1972). (PAaB.) Poetik; 1969, serie II nr. 1, s. 94.

Prætorius, Nini: Subjekt og objekt: en afhandling om psykologiens grundlagsproblemer. Kbh.: Thaning \& Appel, 1981. (Ole Andkjær Olsen.) Kultur \& Klasse 43; 1982, s. 89-91.

Richards, I. A.: Litteraturkritikkens principper. Kbh.: Jørgen Paludans forlag, 1968 (orig. udg. 1924). (S.K.) Poetik; 1968, serie I nr. 4, s. 74-75.

Rosengren, Karl Erik: Sociological aspects of the literary system. Stockholm: Natur och Kultur, 1968. (pm: Videnskabelig litteratursociologi.) Poetik; 1969, serie II nr. 3, s. 94.

Schanz, Hans-Jørgen: Trek af behovsproblematikkens idehistorie med serligt henblik på Marx og Engels. Århus: Modtryk, 1981. (Preben Kaarsholm: Teorien om de menneskelige behov hos Schanz.) Kultur \& Klasse 43; 1982, s. 85-88.

Schlesier, Renante: Konstruktionen der Weiblichkeit bei Sigmund Freud. Frankfurt a.M.: Europäische Verlagsanstalt, 1981. (Judy Gammelgaard: Sporene af fortrengt kvindelighed.) Kultur \& Klasse 47; 1983, s. 121-124. Searle, John R.: Speech Acts. An Essay in the Philosophy of Language. New York: Cambridge University Press, 1969. (Chr. Kock.) Poetik; 1969, serie II nr. 1, s. 95-96.

Sørensen, Peer E.: Elementer litteratursociologi. Et essay om litteratursociologiske grundproblemer. Århus: GMT, 1973. (Peter Madsen: Abstrakt-almen litteratur-sociologi.) Poetik 24; 1975, 6. årg. nr. 4, s. 56-62.

Thomsen, Søren Ulrik: Mit lys brender. Omrids af en ny poetik. Kbh.: Vindrose, 1985. (Martin Zerlang: Husk deden, grib dagen, tand lyset!') Kultur \& Klasse 52; 1986, s. 66-68.

Trivi-serien. Kbh.: Munksgård. (Per Seeberg Friis.) Poetik 25; 1975, 7. årg. nr. 1, s. 160164.

Wollen, Peter: Signs and Meaning in the Cinema, Cinema One 9. London: Secker \& Warburg, 1969. (S.K.). Poetik; 1969, serie II nr. 2, s. 12.

Zerlang, Martin: Bandernes klassekamp i Danmark. Kbh.: Medusa, 1976. (Leif Emerek: Bondernes klassekamp.) Kultur \& Klasse 33; 1978, s. 102-111. 